\title{
A NEW FAMILY, GENUS AND SPECIES OF BAT (MAMMALIA : CHIROPTERA) FROM THAILAND
}

\author{
BY \\ JOHN EDWARDS $\frac{\text { HILL }}{k}$
}

$P p$ 30I-336; 8 Text-figures

BULLETIN OF

THE BRITISH MUSEUM (NATURAL HISTORY) ZOOLOGY Vol. 27 No. 7

LONDON : 1974 
THE BULLETIN OF THE BRITISH MUSEUM (NATURAL HISTORY), instituted in I949, is issued in five series corresponding to the Departments of the Museum, and an Historical series.

Parts will appear at irregular intervals as they become ready. Volumes will contain about three or four hundred pages, and will not necessarily be completed within one calendar year.

In I965 a separate supplementary series of longer papers was instituted, numbered serially for each Department.

This paper is Vol. 27, No. 7 of the Zoological series. The abbreviated titles of periodicals cited follow those of the World List of Scientific Periodicals.

World List abbreviation :

Bull. Br. Mus. nat. Hist. (Zool.)

(C) Trustees of the British Museum (Natural History), I974 


\title{
A NEW FAMILY, GENUS AND SPECIES OF BAT (MAMMALIA : CHIROPTERA) FROM THAILAND
}

\author{
By J. E. HILL \\ INTRODUCTION
}

While Curator of Terrestrial Vertebrates at the Centre for Thai National Reference Collections, Bangkok, the late Kitti Thonglongya became especially interested in the bats of Thailand. His enthusiasm has led in the past few years to the discovery of two new species (Rhinolophus marshalli Thonglongya, 1973, Hipposideros lekaguli Thonglongya \& Hill, I974) in Thailand, and has added other species (Rhinolophus paradoxolophus, Myotis annectans, Pipistrellus cadornae) to the Thai fauna (Thonglongya, I973; Hill \& Thonglongya, I972). He was also responsible for the discovery in the collections of the Bombay Natural History Society of an undescribed genus and species of Indian fruit bat (Latidens salimalii Thonglongya, I972). In the latter part of 1973 he obtained specimens in southern Thailand which he thought might represent an unknown genus and species justifying perhaps the establishment of a further higher category within the Microchiroptera. Specimens sent to the British Museum (Natural History), London, fully confirmed his initial opinion, and showed the new genus to differ sufficiently from the established categories of the Microchiroptera to warrant the proposal of a further family.

Originally, the intention had been to describe this remarkable new bat in a joint paper. With this in view, a detailed comparative study was begun in London to establish and evaluate its diagnostic features, many already recognized by Kitti Thonglongya during his preliminary examination in Thailand. As a result of his sudden and untimely death in February I974, the Applied Scientific Research Corporation of Thailand, through Dr Prasert Lohavanijaya, the Director of the Centre for Thai National Reference Collections, has entrusted me with the preparation of the account. In these circumstances I deem it an honour and a privilege to recognize the contribution made by my former friend and colleague by associating his name with the most outstanding and significant discovery that he made in his studies of the bats of his country.

\section{DIAGNOSES AND DESCRIPTION}

GRASEONYGTERIDAE fam. nov.

Diagnosis. Similar in some respects to the Rhinopomatidae and to the Emballonuridae but second finger with one very short bony phalange, usually ankylosed to the metacarpal and with an equally short cartilaginous tip. As in these families the premaxillae not fused to surrounding or adjacent parts. However, they are united anteriorly to enclose a large anterior palatal vacuity and posteriorly to 
surround the narial aperture ; palatal branches short, solidly ankylosed throughout their length to form a posteriorly projecting, tapered spine extending across about one half or less of the anterior palatal vacuity which it thus divides into two posteriorly confluent foramina; narial branches extending upwards to lie posteriorly on the surface of the maxillae and nasals as a thin, laminar, posteriorly rectangular plate, with no trace of a median suture, the inner margin of this structure forming a narrow, sub-tubular, anteriorly directed flange which borders the lateral and upper parts of the narial opening. Humerus with trochiter or greater tuberosity as large as trochin or lesser tuberosity, trochiter extending proximally beyond the head of the humerus ; a shallow supraglenoid recess between the proximal base of the head of the humerus and the base of the trochiter ; anterior face of proximal part of shaft of humerus flattened in its central part, lacking any median deltoid ridge, instead a slightly elevated area at the base of the trochiter, extending distally along the proximal part of the shaft as a short dorsal flange supporting the trochiter, with a similar but shorter ventral flange supporting the trochin; capitellum slightly displaced from line of shaft ; epitrochlea or medial process a little less than half as wide as distal articular surface, with small epitrochlear or distal spinous process. Sternum not especially modified; shoulder girdle normal; last cervical vertebra not fused with first thoracic; lower three thoracic vertebrae fused, their boundaries faintly visible; lumbar vertebrae except last two solidly ankylosed, the last two free; sacral vertebrae fused, their boundaries obliterated or nearly so. Pelvis small, weak, ascending ramus of pubis short, without definite acicular or pubic spine, the ventral ramus delicate, very thin; ischium with ascending ramus similarly thin and delicate, these structures easily lost in preparation ; fibula thread-like, extending about halfway along the tibia.

\section{CRASEONYCTERIS gen. nov.}

Diagnosis. Most nearly resembling Rhinopoma, the sole genus of the Rhinopomatidae, but differing as above and further in normal, slightly crescentic nostrils which are not slit-like or valvular although as in Rhinopoma they open directly anteriorly in the face of a thickened, vertical narial pad or plate ; ridge-like dermal protrusion surmounting narial plate lower and narrower ; ears not joined anteriorly by a band of integument ; tragus narrowed and rounded at the tip, not truncate, and with an oblate swelling in the centre of its anterior margin. Distal phalange of third digit very long, reflexed beneath wing in specimens preserved in alcohol; distal phalange of fourth digit similarly reflexed ; no external tail, the uropatagium not shortened. Braincase more inflated and more globular than in Rhinopoma; postorbital region less markedly constricted; lateral rostral swellings less inflated, not projecting anteriorly to surpass the narial aperture which slopes posteriorly and is not nearly vertical as in Rhinopoma ; zygomata less expanded ; coronoid process low, below height of articular process. Dentition similar to that of Rhinopoma, the dental formula $\mathrm{i} \frac{1}{2}, \mathrm{c} \frac{1}{1}, \mathrm{pm} \frac{1}{2}, \mathrm{~m} \frac{3}{3}=28$ as in that genus, but upper incisors relatively much larger and third upper molar a little more reduced.

TyPE SPECIEs. Craseonycteris thonglongyai sp. nov. 
REMARKs. The name of the new genus is derived from $\kappa \rho \tilde{a} \sigma s$ or $\kappa \rho \tilde{\alpha} \sigma \epsilon \epsilon^{\prime} \omega$, a mixing or blending, with vvктєрis, a bat, in allusion to the combination of features presented by this notable discovery. Since the genus is proposed to include only the type species, one description may serve for both.

\section{Craseonycteris thonglongyai sp. nov.}

Holotype. Thai National Reference Collections No. 54-3871. Adult ${ }^{\star}$. Cave near the Forestry Station, Ban Sai Yoke, Kanchanaburi, Thailand, $14^{\circ} 26^{\prime} \mathrm{N}$, $98^{\circ} 5 \mathrm{I}^{\prime} \mathrm{E}$. Collected 8 December $\mathrm{I} 973$ by Kitti Thonglongya. Original number KT 57Io. In alcohol, skull extracted.

Other material. Thai National Reference Collections (in alcohol unless stated) :

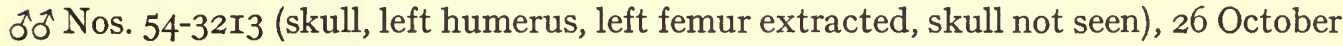
I973 ; 54-3865 (disarticulated skeleton), 54-3866-3870 (skulls extracted), 54-3872$3873,54-3874-3875$ (skulls extracted), 54-3876, 54-3884 (skull extracted), 54-3886, 54-3887-3888 (skulls extracted), 54-3889, 8 December I973; 우 Nos. 54-3230 (skull extracted, right fibula exposed), 28 October I973; 54-3877, 54-3878388I (skulls extracted), 54-3882-3883, 54-3885, 8 December I973. Collected by Kitti Thonglongya at or near the type locality.

This account is based on the specimens listed. A total of fifty-two numbers is allocated to specimens of this bat in the field catalogue maintained by Kitti Thonglongya : those not examined in the preparation of this study have remained in the Thai National Reference Collections and include skins, skulls, skeletons and specimens preserved in alcohol (J. T. Marshall, in litt.). The entire representation came from one or other of two caves near the Forestry Station, Ban Sai Yoke, probably about $2 \mathrm{~km}$ along the Kwae Noi River past its junction with the Huay Mae Nam Noi River (J. T. Marshall, in litt.). Specimens collected in October I973 came apparently from 'Tham Wang Phra', those in December from 'Namtok Sai Yoke'. The final disposition of the series examined at the British Museum (Natural History) has yet to be decided but it is expected that the specimens will remain in London for an indefinite period, some permanently.

Description. A very small bat (length of forearm $22-26 \mathrm{~mm}$ ), dorsally greyish brown, ventrally rather greyer, some specimens with a slight reddish tinge dorsally (from alcohol), membranes dark. Muzzle (Fig. I) rather suiform, slightly swollen laterally; anterior part of chin similarly swollen, the swelling faintly divided medianly; anteriorly muzzle with a thickened, fleshy vertical narial pad or plate surmounted by a low dermal ridge extending across the central part of the narial pad; nostrils wide, slightly crescentic, opening directly anteriorly in the face of the narial pad, sharply inclined to the horizontal, separated by a relatively wide internarial septum which broadens above the nostrils to form the base of the low dermal ridge. Shallow grooves extend upwards from the upper corner of each nostril to separate the dermal ridge from the lateral elements of the narial pad; shallow depressions extend downwards from the lateral margins of the internarial septum towards the upper lip ; central part of lower lip raised by a smooth, naked swelling 


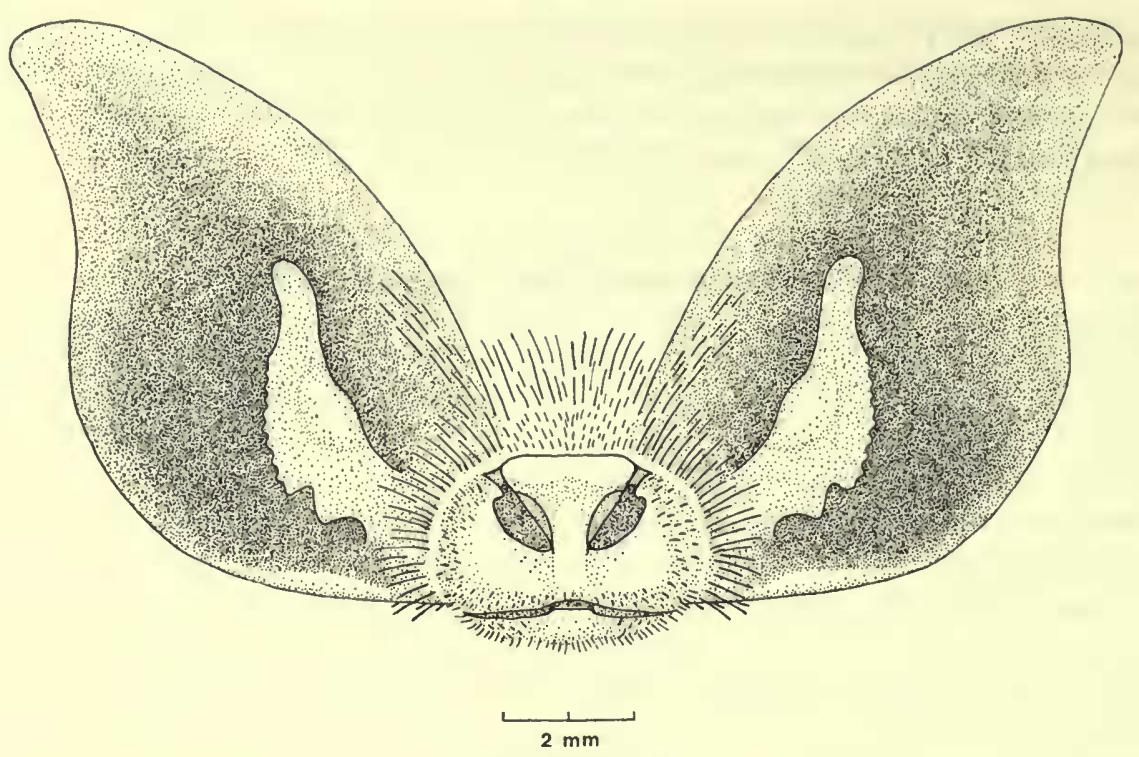

FIG. I. Craseonycteris thonglongyai. Head.

immediately anterior to and extending across the lower incisors. Narial pad and median anterior part of lower lip naked; lateral swellings of muzzle and of chin sparsely covered with short, rather stiff hairs, underside of chin and throat only lightly furred.

Eyes small, largely concealed in fur ; ears (Fig. I) very large and rather membranaceous, reaching beyond the tip of the muzzle when laid forward. Ear rounded at the tip, anterior margin originating just above eye, without basal lobe, convex, posterior margin moderately concave just beneath tip, then straight, proximal half strongly convex, inserted quadrately just behind angle of mouth, antitragus poorly developed, little more than a thickening of the ear membrane. Outer surface of conch with a few sparse hairs in its proximal half, inner surface with a diffuse band of sparse hairs posterior and parallel to the proximal part of its anterior margin, a few sparse hairs in its distal part.

Tragus (Fig. I) a little less than one half the length of the ear, basally narrow beneath a small, more or less triangular posterior basal lobe, then broadly expanded, its greatest width at about one half its length, narrowing abruptly to a rounded tip. Anterior part of tragus with distinct oblate thickening about halfway along its length, the thickened area extending across one half of the width of the tragus at this point. Tragus with anterior margin slightly concave proximally, then at the oblate thickening slightly convex beneath a shallow concavity, distal part of margin slightly convex to tip ; posterior margin slightly concave distally, then convex and serrated at the widest part of the tragus, curving abruptly, almost angularly to a shallow rounded emargination just above the posterior basal lobe.

Propatagium or antebrachium broad, originating proximally at a point level with the shoulder joint, extending distally to the distal end of the first metacarpal. 
Thumb short, with well-developed claw; membrane between thumb and second metacarpal broad proximally, anchored to the end of the first metacarpal, tapering to a distal termination at a point about halfway along the second metacarpal. Second digit free anteriorly in its distal part, with long metacarpal and one very short bony phalange, usually fused to the metacarpal, the junction visible under relatively high magnification, often marked by a slight broadening of the metacarpal, the digit tipped by a tapered cartilage which is approximately equal in length to the short bony phalange. Membrane lying between second and third digits terminating distally about one quarter or a little more along the length of the second phalange of the third digit from its junction with the first phalange. Third digit with two phalanges, no trace of a third, its metacarpal shorter than the metacarpal of the second digit, the second phalange very long, about three times as long as the first phalange and approximately equal in length to the third metacarpal, strongly reflexed beneath wing in specimens preserved in alcohol. Metacarpal of fourth digit a little longer than that of third digit but shorter than second metacarpal, its first phalange very short, in length about one sixth that of the associated metacarpal, second phalange long, about three times the length of the first phalange, slightly reflexed beneath wing. Metacarpal of fifth digit about as long as fourth metacarpal,
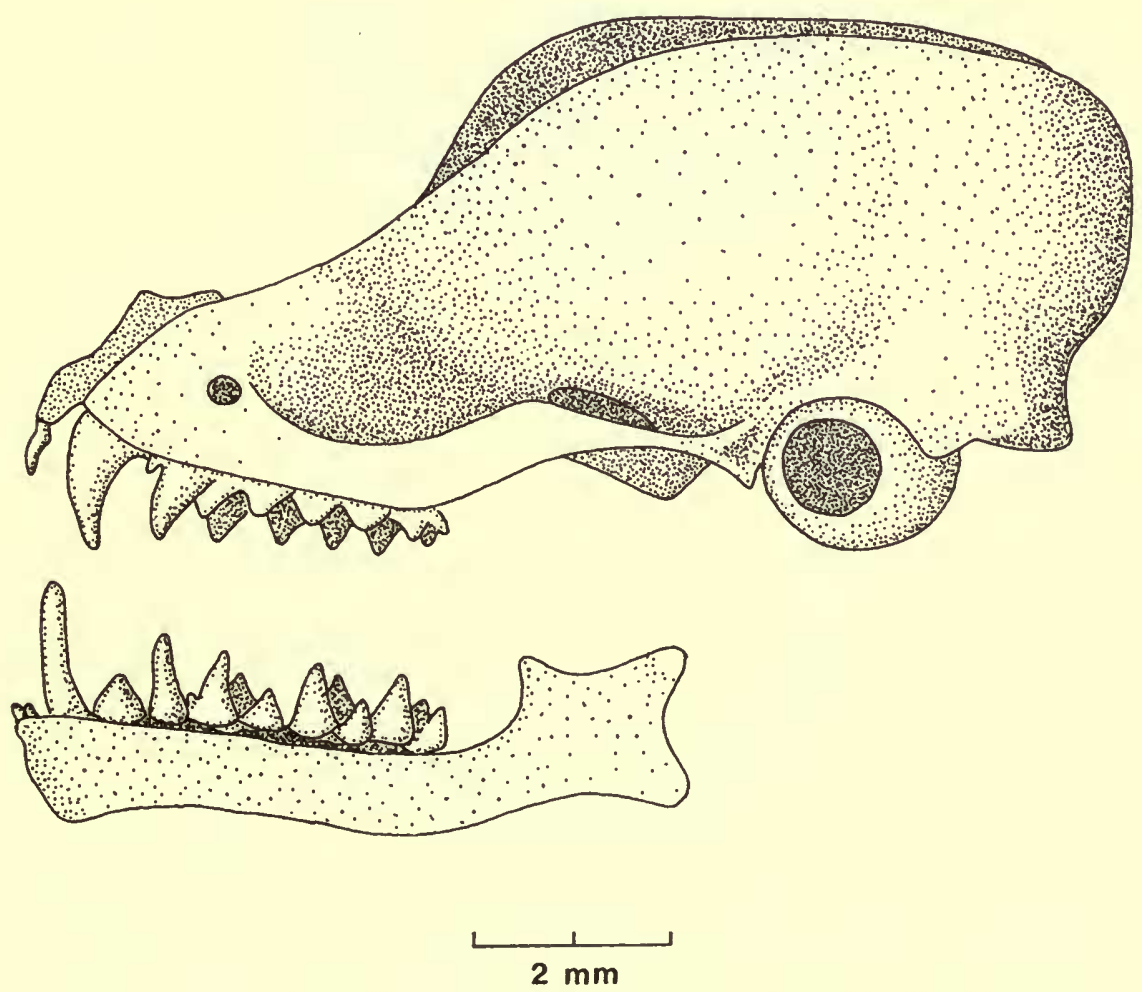

FIG. 2. Craseonycteris thonglongyai. Holotype. Lateral aspect of skull. 
its first phalange short, about one quarter the length of its metacarpal, the second phalange slightly exceeding the first in length.

No external tail, uropatagium moderate, narrow proximally between upper part of legs to knees, wider distally, its posterior margin slightly curved, terminating medianly at a line a little beyond halfway from knees to ankles, calcar absent, membranes inserted 3-4 $\mathrm{mm}$ above the ankle; a few short hairs on the ventral surface of the endopatagium, clustered at and about the distal end of the humerus, fur not extending on to the uropatagium. Foot long, narrow and slender, the phalangeal formula $2-3-3-3-3$, the toes subequal in length, with a few long hairs on the dorsal surface. A rounded glandular swelling at base of underside of throat, well developed and prominent in males, much less so or absent in females. Penis relatively massive, short and broad, moderately covered with short hairs, preputial

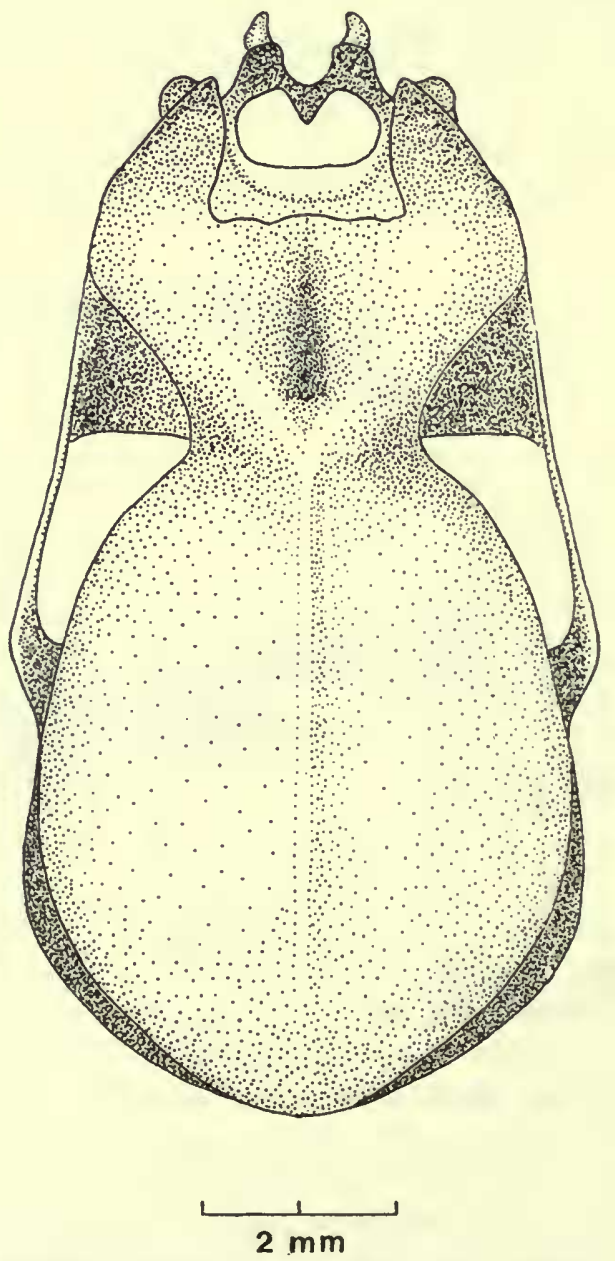

FIG. 3. Craseonycteris thonglongyai. Holotype. Dorsal aspect of skull. 


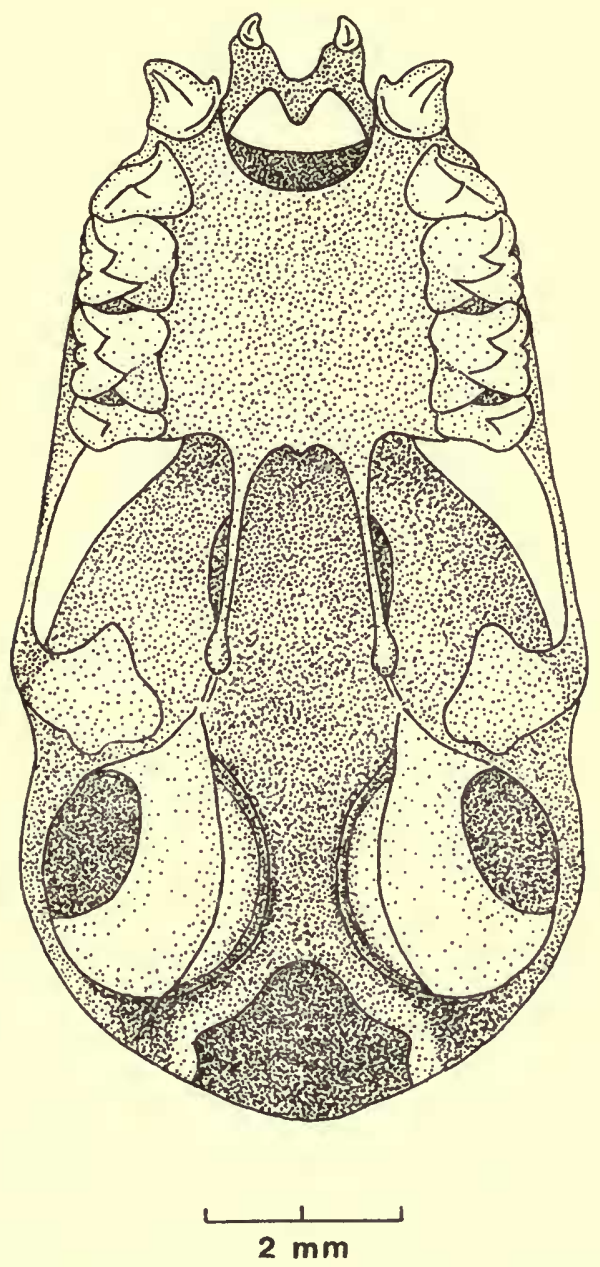

FIG. 4. Craseonycteris thonglongyai. Holotype. Ventral aspect of skull.

opening small, rounded; vulva transverse, set in a fleshy elevation. One pair pectoral and one pair pubic nipples, the latter closely set and situated just anterior to the genital eminence.

Skull (Figs. 2-5) very small (condylobasal length 9.5-10.1 mm) with slightly inflated, globose braincase; no lambdoid crests ; prominent sagittal crest extending from rear of braincase to frontal region immediately above narrowest postorbital point, its crest slightly higher frontally than posteriorly; postorbital region not especially constricted. Rostrum wide, laterally expanded; no postorbital processes or evident supraorbital ridges; combined nasals wider than long; lateral rostral swellings well developed and prominent, not extending laterally to project beyond the narial aperture at its sides, swellings separated dorsally by a narrow median rostral depression, deeper posteriorly than anteriorly ; narial opening sloping posteriorly, 


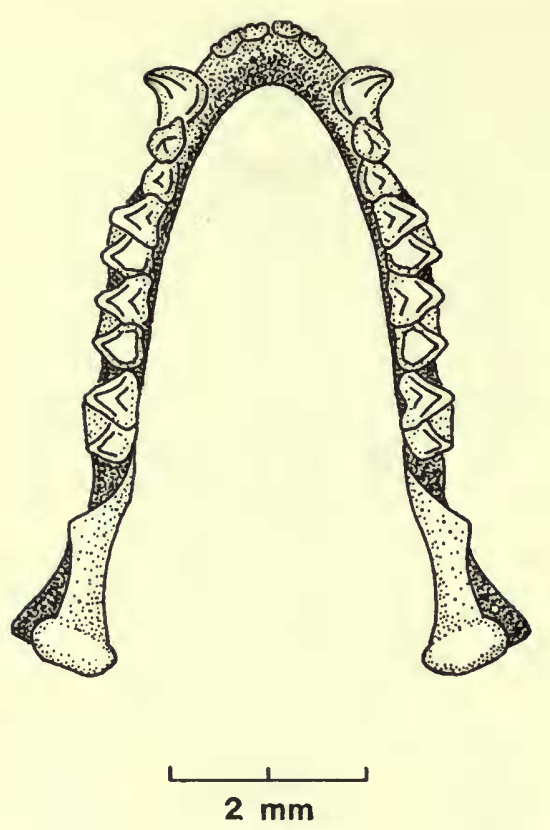

FIG. 5. Craseonycteris thonglongyai. Holotype. Dorsal aspect of mandible.

flanked by the lateral rostral swellings. Premaxillae not fused to adjoining parts but completely united; palatal branches small, totally co-ossified with no trace of a suture, anteriorly a U-shaped emargination between the incisors; posteriorly the fused palatal branches form a narrow, tapered spike extending across about one half or a little less of the large anterior palatal foramen ; narial branches exceptionally developed to extend upward to the apex of the narial aperture where they are totally fused, forming a thin lamina or plate, rectangular posteriorly, lying on the maxillae and nasals, its inner edge produced anteriorly to form a thin, sub-tubular flange around the lateral and upper parts of the narial opening ; entire premaxillary structure firmly connected by tough tissue to the rear of the narial pad which apparently it serves to support. Anteorbital foramen small ; zygoma unexpanded, slender but with well-developed, rounded jugal process; palate short, wide, with large anterior foramen closed anteriorly by the premaxillae, its posterior wall extending along a line lying just behind the anterior faces of the upper premolars $\left(\mathrm{pm}^{4-4}\right)$, partially divided medianly by the spike-like rearward extension of the fused palatal branches of the premaxillae; maxillary toothrows slightly curved anteriorly; palate terminating posteriorly on a line slightly in advance of the posterior faces of the third upper molars $\left(\mathrm{m}^{3-3}\right)$. Mesopterygoid fossa not especially narrow, its width a little less than one third of the external width across $\mathrm{m}^{3}-\mathrm{m}^{3}$; no bony post-palate, the palation a little behind a line joining the posterior faces of $\mathrm{m}^{3-3}$; pterygoid wings moderately developed, divergent ; no basioccipital pits ; tympanic bullae relatively large, flattened on the inner face. Coronoid process low, its tip below the level of the articular process, angular process slightly deflected. 
Soft palate (Fig. 6) with six transverse ridges, the first curved on each side to the median line, second ridge nearly straight, third more definitely incurving to median line, ridges four and five slightly less curved, sixth ridge straight ; first ridge with shallow median division, ridges two to five with small median notch.

Dental formula $\mathrm{i} \frac{1}{2}, \mathrm{c} \frac{1}{1}, \mathrm{pm} \frac{1}{2}, \mathrm{~m} \frac{3}{3}$; tips of upper incisors $\left(\mathrm{i}^{2-2}\right)$ slightly convergent, $\mathrm{i}^{2}$ relatively large, separated rather widely from canine, flattened antero-posteriorly, longer than wide, with posteriorly a strong basal cingulum, the cusp acutely triangular in frontal aspect. Upper canine with moderately tall, slender shaft, its base triangular with narrow internal cingulum and small but prominent antero-internal

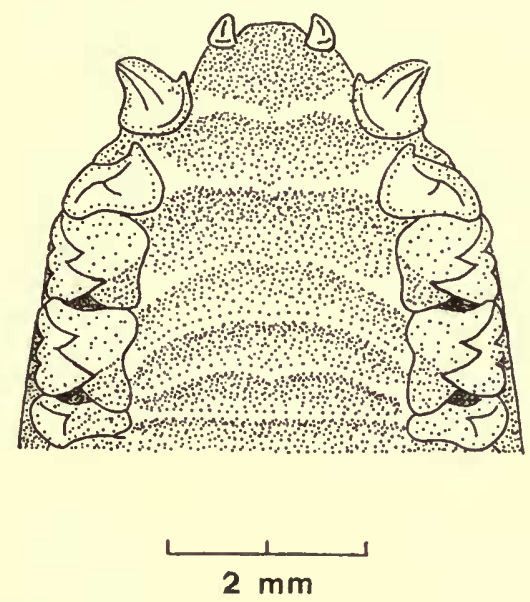

FIG. 6. Craseonycteris thonglongyai. ô TNRC 54-3872. Palate ridges.

cusp, readily visible from the front. Upper premolar $\left(\mathrm{pm}^{4}\right)$ large, with wide lingual shelf and prominent anterior cingulum cusp, easily seen from the side, the posterior margin of the tooth centrally slightly concave. First and second upper molars $\left(\mathrm{m}^{1-2}\right)$ with hypocone markedly lower than the protocone, the hypoconal basin of $\mathrm{m}^{1}$ more or less contiguous with the protoconal basin, the two basins in $\mathrm{m}^{2}$ slightly more sharply demarcated from each other in teeth with little wear, the rear face of each tooth sharply concave in its central part, isolating the hypocone and metacone to some extent, and producing a wide space between the medio-posterior part of the tooth and the anterior face of the succeeding tooth. Third upper molar $\left(\mathrm{m}^{3}\right)$ reduced, the metastyle, metacone and hypocone lost, the mesostyle present but displaced internally, only the first ridge or paracrista and a reduced second ridge or postparacrista remaining, the latter terminating at the mesostyle which lies posteriorly in the centre of the rear margin of the tooth, the pre-metacrista and metacrista lost. Lower incisors $\left(\mathrm{i}_{1-2}\right)$ about equal in size, tricuspid, the central cusp slightly the larger, the teeth long and narrow, lacking any low posterior supporting cusps, not imbricated, $\mathbf{i}_{2}$ separated from the canine by a small diastema. Lower canine with moderately long, slender shaft, rising from a narrow cingulum, with no accessory cusps. First lower premolar $\left(\mathrm{pm}_{2}\right)$ large, longer than wide, a little longer but slightly narrower than the second lower premolar $\left(\mathrm{pm}_{4}\right)$, with narrow cingulum and large cusp, 
triangular in lateral profile. Second lower premolar $\left(\mathrm{pm}_{4}\right)$ slightly compressed in toothrow, rather caniniform, its base about as long as wide, with narrow cingulum and tall, slender, rounded spike-like cusp, a little exceeding the height of $\mathrm{pm}_{2}$ and equal in height to the first lower molar $\left(\mathrm{m}_{1}\right)$, the cusp hollowed posteriorly. Lower molars $\left(\mathrm{m}_{1-3}\right)$ with no especial peculiarities, $\mathrm{m}_{3}$ a little reduced, its posterior triangle slightly smaller than the anterior triangle, the hypoconid and entoconid reduced.

Humerus (Fig. 7) with trochiter or greater tuberosity about as large as trochin or lesser tuberosity, extending proximally beyond the head of the humerus, trochiter with small articular surface on its posterior face, separated from head of humerus by a distinct groove, the articular surface of head extending across the groove to the ventral face of the trochiter ; trochin well developed but not reaching proximally to head of humerus which is rounded, not compressed laterally. Proximal face of - humerus lacking distinct ridges, groove between trochiter and head of humerus deepened at its anterior end to form a shallow supraglenoid fossa. Anterior face of shaft of humerus flattened medianly in its proximal part, lacking any median deltoid ridge, instead a low but distinct elevation extending dorsad from the base of the trochiter to edge of flattened proximal part of shaft to form a short, narrow dorsal flange beneath the trochiter; trochin similarly supported by a thin ventral flange extending along a short part of the opposite side of the shaft, which itself is slightly curved, the curve simple. Radial fossa indistinct; capitellum slightly displaced

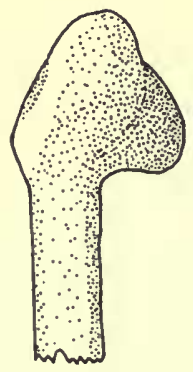

a

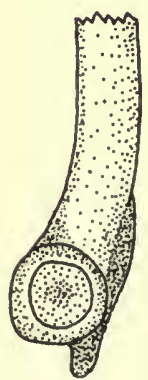

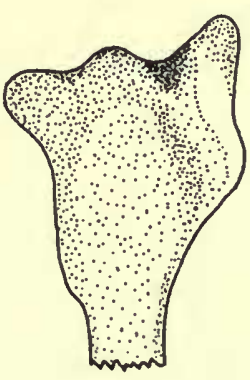

b

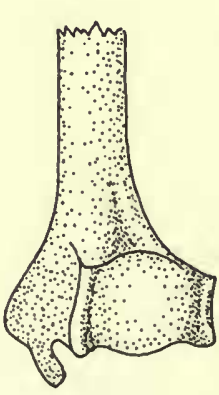

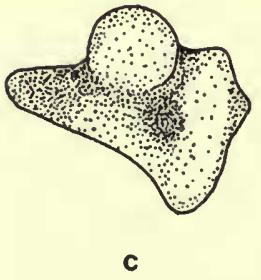

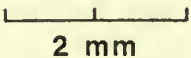

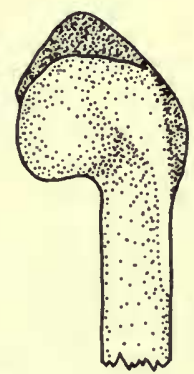

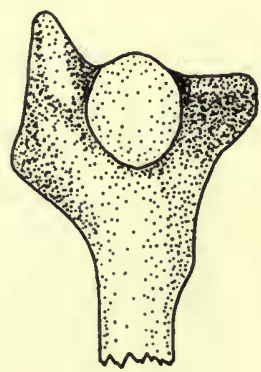

d
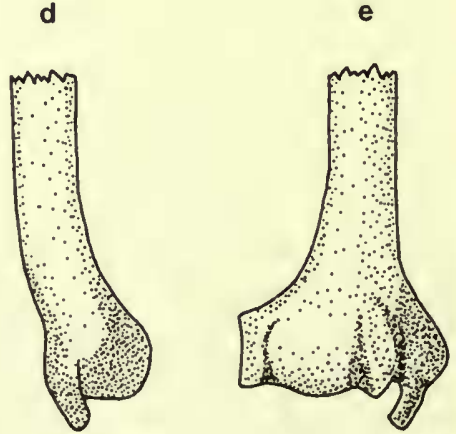

FIG. 7. Craseonycteris thonglongyai. đTNRC 54-3865. Left humerus. a. Dorsal aspect. b. Anterior aspect. c. Proximal aspect. d. Ventral aspect. e. Posterior aspect. 


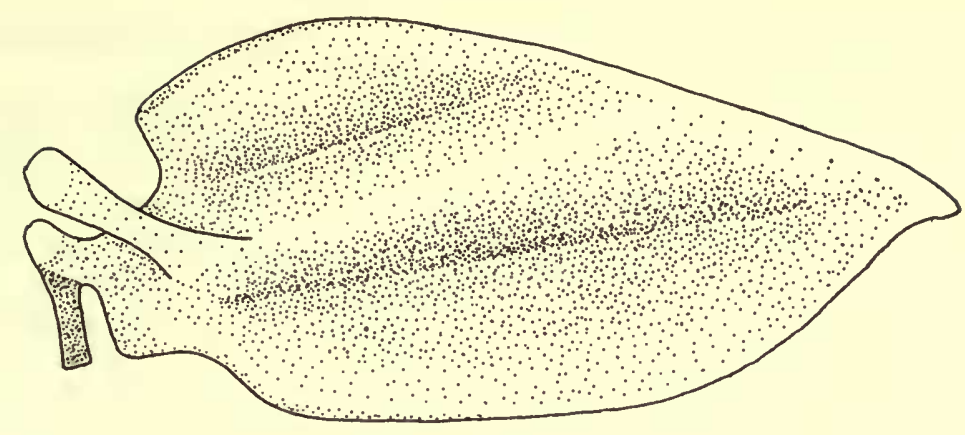

a

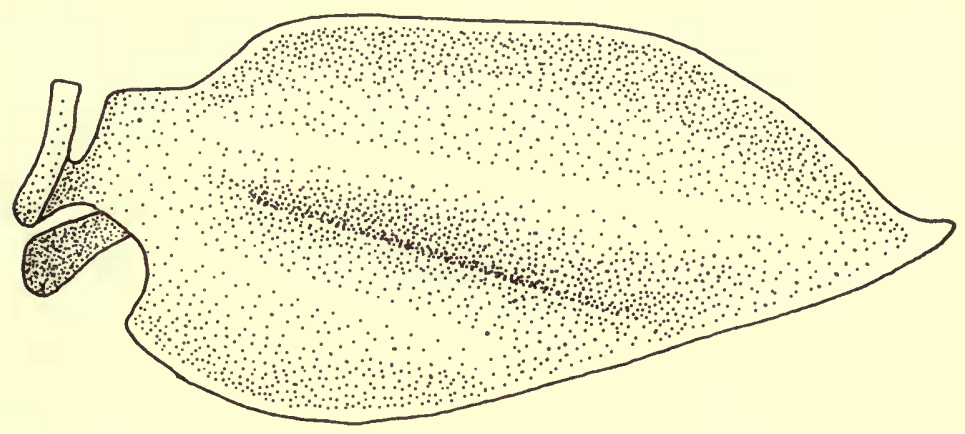

b

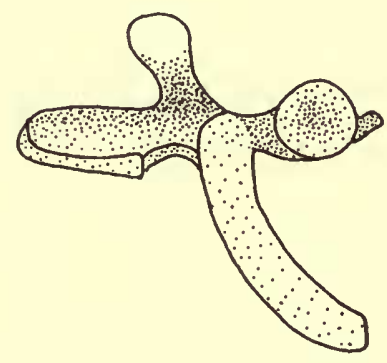

c

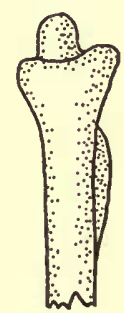

d

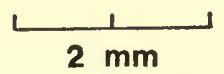

Fig. 8. Craseonycteris thonglongyai. ô TNRC 54-3865. a. Dorsal aspect of left scapula.

b. Ventral aspect of left scapula. c. Anterior aspect of left scapula. d. Medial aspect of proximal end of left femur.

from line of shaft, its principal articular surface spherical, not compressed or oblique ; lateral surface narrow, not extending distally as far as the principal part of the capitellum; trochlea similarly narrow, extending distally about as far as the principal articular surface ; epitrochlea or medial process about half as wide as distal articular 
surface, with small epitrochlear or distal spinous process, extending distally beyond the articular surface.

Sternum not especially modified; presternum or manubrium T-shaped, with broad, dorso-ventrally flattened lateral extensions or processes; anterior part of presternum with moderately developed keel, posterior extension broad, flattened dorso-ventrally, with low keel; mesosternum with longitudinal median ventral ridge ; xiphisternum short, parallel-sided, with rounded tip, surrounded by cartilage. Clavicle slender; scapula (Fig. 8, a-c) large, elongate; supraglenoid tuberosity relatively well developed, with small articular face ; coracoid border deeply notched, with narrow, ventrally directed flange; axillary border slightly notched behind glenoid fossa with a shallow postglenoid depression; acromion process slender, recurved antero-ventrally; coracoid process well developed, directed laterad, parallel-sided, its tip simple. Supraspinous fossa about one third the area of the infraspinous fossa, with no especial features ; infraspinous fossa strongly faceted, the antero-medial facet wide, set at a sharp angle to the intermediate facet which is wide distally, the fossa divided more or less medianly by a deep, angular groove ;

\section{TABLE I}

External measurements (in $\mathrm{mm}$ ) of Craseonycteris thonglongyai

\begin{tabular}{|c|c|c|c|c|c|c|c|}
\hline & \multicolumn{4}{|c|}{ ఠర } & \multicolumn{3}{|c|}{ 우 } \\
\hline & $\begin{array}{c}\text { Holotype } \\
\text { o TNRC } \\
54-387 \text { I }\end{array}$ & $\begin{array}{l}\text { No. of } \\
\text { speci- } \\
\text { mens }\end{array}$ & Range & Mean & $\begin{array}{l}\text { No. of } \\
\text { speci- } \\
\text { mens }\end{array}$ & Range & Mean \\
\hline Width of narial pad & $3 \cdot 9$ & I7 & $3 \cdot 8-4 \cdot 3$ & $4^{\cdot I}$ & 8 & $3 \cdot 8-4 \cdot 4$ & $4 \cdot 0$ \\
\hline Width of narial ridge & $2 \cdot 2$ & I7 & $I \cdot 9-2 \cdot 4$ & $2 \cdot 2$ & 9 & $2 \cdot 0-2 \cdot 5$ & $2 \cdot 2$ \\
\hline Length of ear & $9 \cdot 6$ & 17 & $9 \cdot 0-10 \cdot 0$ & $9 \cdot 5$ & 9 & $9 \cdot 0-10 \cdot 2$ & $9 \cdot 8$ \\
\hline Width of ear & $7 \cdot 9$ & I7 & $7 \cdot 3-8 \cdot 5$ & $7 \cdot 9$ & 9 & $7 \cdot 3-8 \cdot 3$ & $7 \cdot 9$ \\
\hline Length of tragus & $4^{\circ} \mathrm{O}$ & I7 & $3 \cdot 8-4 \cdot 2$ & $4^{\circ} \mathrm{O}$ & 9 & $3 \cdot 8-4 \cdot I$ & $4 \cdot 0$ \\
\hline Length of tibia & $12 \cdot 3$ & I6 & I I $\cdot 9-12 \cdot 9$ & $12 \cdot 3$ & 9 & $\mathrm{II} \cdot 7-\mathrm{I} 2 \cdot 8$ & $12 \cdot 3$ \\
\hline Length of foot (with & & & & & & & \\
\hline claw) & $6 \cdot 0$ & I7 & $5 \cdot 9-6 \cdot 8$ & $6 \cdot 3$ & 9 & $5 \cdot 8-6 \cdot 6$ & $6 \cdot 2$ \\
\hline Length of forearm & $24 \cdot 4$ & I6 & $24 \cdot I-25 \cdot 2$ & $24 \cdot 6$ & 9 & $22 \cdot 5-25 \cdot 8$ & $24^{\circ} 9$ \\
\hline Length of thumb & $4 \cdot 9$ & I7 & $4 \cdot 6-5 \cdot 3$ & $5 \cdot 0$ & 9 & $4 \cdot 6-5 \cdot 3$ & $4^{\circ} 9$ \\
\hline Length of IIm & $25 \cdot 0$ & I7 & $24 \cdot 1-25 \cdot 6$ & 24.7 & 9 & $23 \cdot 9-26 \cdot 5$ & $25 \cdot 6$ \\
\hline Length of $\mathrm{II}^{1}$ & 0.52 & I7 & $0 \cdot 40-0.55$ & 0.50 & 9 & $0.45-0.54$ & $0.5 \mathrm{I}$ \\
\hline Length of $\mathrm{II}^{\mathrm{d}}$ cartilage & 0.63 & I7 & $0.40-0.63$ & 0.52 & 9 & $0.42-0.60$ & 0.51 \\
\hline Length of III $\mathrm{m}$ & $20 \cdot 6$ & I6 & $19 \cdot 8-21 \cdot 6$ & $20 \cdot 7$ & 9 & $19 \cdot 7-21 \cdot 7$ & $2 I \cdot I$ \\
\hline Length of III $^{1}$ & $6 \cdot 9$ & I7 & $6 \cdot 4-7 \cdot 0$ & $6 \cdot 7$ & 9 & $6 \cdot 5-7 \cdot 1$ & $6 \cdot 8$ \\
\hline Length of III $^{2}$ & $20 \cdot \mathrm{I}$ & I6 & I $8 \cdot 7-2 I \cdot 5$ & $20 \cdot 3$ & 9 & $19 \cdot 4-21 \cdot 2$ & $20 \cdot I$ \\
\hline Length of IVm & $22 \cdot 7$ & I7 & $21 \cdot 7-23 \cdot 2$ & $22 \cdot 4$ & 9 & $21 \cdot 7-23 \cdot 8$ & $23 \cdot I$ \\
\hline Length of IV 1 & $3 \cdot 9$ & I7 & $3 \cdot 5-4 \cdot 2$ & $3 \cdot 9$ & 9 & $3 \cdot 6-4 \cdot 3$ & $3 \cdot 9$ \\
\hline Length of $\mathrm{IV}^{2}$ & $10 \cdot 3$ & I7 & $9 \cdot 7-10 \cdot 7$ & $10 \cdot 2$ & 9 & $9 \cdot 7-10 \cdot 8$ & $10 \cdot 3$ \\
\hline Length of $\mathrm{Vm}$ & $22 \cdot 7$ & I7 & $21 \cdot 7-23 \cdot 0$ & $22 \cdot 4$ & 9 & $2 I \cdot 8-23 \cdot 7$ & $23 \cdot 2$ \\
\hline Length of $V^{1}$ & $5 \cdot 7$ & I7 & $5 \cdot 2-5 \cdot 7$ & $5 \cdot 4$ & 9 & $5 \cdot 2-5 \cdot 9$ & $5 \cdot 6$ \\
\hline Length of $\mathrm{V}^{2}$ & $6 \cdot 0$ & I6 & $6 \cdot I-7 \cdot 0$ & $6 \cdot 3$ & 9 & $5 \cdot 9-6 \cdot 6$ & $6 \cdot 2$ \\
\hline
\end{tabular}

The nomenclature used for the digits in this Table, in Table 3 and in Table 4 is an extension of Andersen (1905: 246, footnote), i.e. IIId is the third digit, IIIm its metacarpal, and III ${ }^{1}$ and III $^{2}$ its first and second phalanges. 
TABLE 2

Cranial measurements (in $\mathrm{mm}$ ) of Craseonycteris thonglongyai

\begin{tabular}{|c|c|c|c|c|c|c|c|}
\hline & \multicolumn{5}{|c|}{30} & \multicolumn{2}{|l|}{ 우우 } \\
\hline & $\begin{array}{c}\text { Holotype } \\
\text { o TNRC } \\
54-3871\end{array}$ & $\begin{array}{l}\text { No. of } \\
\text { speci- } \\
\text { mens }\end{array}$ & Range & Mean & $\begin{array}{l}\text { No. of } \\
\text { speci- } \\
\text { mens }\end{array}$ & Range & Mea \\
\hline Greatest length of skull & II $\cdot I$ & I I & $10 \cdot 6-11 \cdot 5$ & I I 2 & 5 & $10 \cdot 3-I I \cdot I$ & $10 \cdot 9$ \\
\hline Condylocanine length & $9 \cdot 9$ & 12 & $9 \cdot 9-10 \cdot \mathbf{I}$ & IO०O & 5 & $9^{\cdot 6-10 \cdot 0}$ & $9 \cdot 9$ \\
\hline Condylobasal length & $10 \cdot 0$ & II & $10 \cdot 0-10 \cdot 3$ & IO·I & 5 & $9 \cdot 5^{-10} \cdot \mathrm{I}$ & $9 \cdot 8$ \\
\hline Palatal length & $4 \cdot 0$ & I I & $3 \cdot 9-4 \cdot 2$ & $4 \cdot I$ & 5 & $3 \cdot 8-4 \cdot I$ & $3 \cdot 9$ \\
\hline Palatilar length & $3 \cdot 8$ & I I & $3 \cdot 7-3 \cdot 9$ & $3 \cdot 8$ & 5 & $3 \cdot 6-3 \cdot 9$ & $3 \cdot 7$ \\
\hline $\begin{array}{l}\text { Width across ante- } \\
\text { orbital foramina }\end{array}$ & $3 \cdot 8$ & 12 & $3 \cdot 7-4 \cdot 0$ & $3 \cdot 9$ & 5 & $3 \cdot 7-3 \cdot 9$ & $3 \cdot 8$ \\
\hline Width across lacrimals & $4 \cdot 4$ & 12 & $4 \cdot 3-4 \cdot 6$ & 4.4 & 5 & $4 \cdot 2-4 \cdot 5$ & $4 \cdot 4$ \\
\hline $\begin{array}{l}\text { Width across rostral } \\
\text { swellings }\end{array}$ & $4 \cdot I$ & I 2 & $4^{\cdot 0-4} \cdot 4$ & $4^{\cdot I}$ & 5 & $3 \cdot 9-4 \cdot 3$ & $4^{\cdot} \cdot 1$ \\
\hline Zygomatic width & $5 \cdot 8$ & 12 & $5 \cdot 5-6 \cdot 0$ & $5 \cdot 8$ & 5 & $5 \cdot 5-5 \cdot 7$ & $5 \cdot 6$ \\
\hline Postorbital width & $2 \cdot 2$ & 12 & $2 \cdot I-2 \cdot 3$ & $2 \cdot 2$ & 5 & $2 \cdot 1-2 \cdot 2$ & $2 \cdot I$ \\
\hline Width of braincase & $5^{\cdot 6}$ & 12 & $5 \cdot 3-5 \cdot 7$ & $5 \cdot 5$ & 4 & $5 \cdot 4-5 \cdot 5$ & $5 \cdot 5$ \\
\hline Height of braincase & $4^{\cdot 1}$ & 12 & $4 \cdot 0-4 \cdot 3$ & $4^{\cdot} \cdot \mathrm{I}$ & 4 & $3 \cdot 9-4 \cdot 0$ & $4^{\cdot 0}$ \\
\hline Mastoid width & $5 \cdot 8$ & 12 & $5 \cdot 7-6 \cdot 0$ & $5 \cdot 8$ & 4 & $5 \cdot 7-5 \cdot 9$ & $5 \cdot 8$ \\
\hline$c^{1}-c^{1}$ & $3 \cdot 0$ & 12 & $2 \cdot 9-3 \cdot 2$ & $3 \cdot 0$ & 5 & $2 \cdot 8-2 \cdot 9$ & $2 \cdot 8$ \\
\hline$m^{3}-m^{3}$ & $4 \cdot 6$ & 12 & $4 \cdot 6-4 \cdot 9$ & $4 \cdot 7$ & 5 & $4 \cdot 5-4 \cdot 6$ & $4 \cdot 6$ \\
\hline Post-palatal width & $\mathrm{I} \cdot 5$ & I 2 & $I \cdot 4-I \cdot 5$ & $I \cdot 5$ & 5 & $I \cdot 4-1 \cdot 5$ & $1 \cdot 4$ \\
\hline Width across pterygoid & & & & & & & \\
\hline wings & $\mathrm{I} \cdot 8$ & 7 & $I \cdot 8-2 \cdot 0$ & $I \cdot 9$ & 5 & $I \cdot 7-2 \cdot 0$ & $\mathrm{I} \cdot 8$ \\
\hline Length of tympanic bulla & $2 \cdot 6$ & 12 & $2 \cdot 4-2 \cdot 7$ & $2 \cdot 6$ & 5 & $2 \cdot 3-2 \cdot 6$ & $2 \cdot 6$ \\
\hline Width of tympanic bulla & $\mathrm{I} \cdot 8$ & I I & $I \cdot 5-I \cdot 9$ & $\mathrm{I} \cdot 7$ & 5 & $I \cdot 6-I \cdot 8$ & $I \cdot 7$ \\
\hline Length of cochlea & $2 \cdot I$ & 12 & $1 \cdot 8-2 \cdot 2$ & $2 \cdot 0$ & 5 & $1 \cdot 8-2 \cdot 2$ & $2 \cdot 0$ \\
\hline Width of cochlea & $2 \cdot 2$ & 12 & $2 \cdot 0-2 \cdot 3$ & $2 \cdot 2$ & 5 & $2 \cdot O-2 \cdot I$ & $2 \cdot I$ \\
\hline Width of basioccipital & $0 \cdot 6$ & 12 & $0.5-0.7$ & $0 \cdot 6$ & 5 & $0 \cdot 5-0 \cdot 6$ & $0 \cdot 6$ \\
\hline$c-m^{3}$ & $3 \cdot 8$ & I 2 & $3 \cdot 7-3 \cdot 9$ & $3 \cdot 8$ & 5 & $3 \cdot 6-3 \cdot 8$ & $3 \cdot 7$ \\
\hline Length of complete & & & & & & & \\
\hline mandible & $6 \cdot 9$ & 12 & $6 \cdot 9-7 \cdot I$ & $7 \cdot 0$ & 4 & $6 \cdot 7-6 \cdot 9$ & $6 \cdot 8$ \\
\hline Length of right ramus & $7 \cdot 0$ & 12 & $7 \cdot 0-7 \cdot 3$ & $7 \cdot 1$ & 4 & $6 \cdot 9-7 \cdot I$ & $7^{\cdot 0}$ \\
\hline $\mathrm{c}-\mathrm{m}_{3}$ & $4^{\circ} \mathrm{O}$ & I 2 & $4 \cdot 0-4 \cdot 2$ & $4 \cdot I$ & 5 & $3 \cdot 9-4^{\bullet} 0$ & $4^{\cdot 0}$ \\
\hline
\end{tabular}

postero-lateral facet about as wide as intermediate facet, with proximally a low ridge extending from the base of the glenoid fossa along but just within the axillary border and distally along the further two thirds of the axillary margin; ventral surface of scapula with four facets, underside of postero-lateral facet rather narrow.

Last cervical vertebra not fused to first thoracic; lower three thoracic vertebrae fused, their boundaries faintly visible; lumbar vertebrae except last two solidly ankylosed, the last two free; sacral vertebrae fused, their boundaries obliterated or nearly so ; two small caudal vertebrae. Pelvis small, weak, the ilia long and very slender ; ascending ramus of pubis short, the depth of the pelvis less than one half of its total length; no definite acicular or pubic spine; ventral ramus of pubis thin and delicate; ischium with similarly thin, delicate ascending ramus, these structures easily lost. Femur (Fig. 8, d) slender, delicate, its proximal part not 
markedly deflected, with strong flange on its anterior face; trochanters small but evident, the lesser trochanter slightly the larger and extending proximally a little further than the greater trochanter. Fibula thread-like, tapered, extending about halfway along the tibia.

Measurements of Craseonycteris thonglongyai appear in Tables I and 2.

Remarks. The species is named to commemorate the late Kitti Thonglongya, formerly Curator of Terrestrial Vertebrates at the Centre for Thai National Reference Collections, whose last discovery it was. His untimely death was a sad loss to his many friends and to mammalogy in southeastern Asia, especially in Thailand where his enthusiasm and energy will be greatly missed.

The suiform muzzle of Craseonycteris thonglongyai has suggested ( $\mathrm{H}$. Elliott McClure, in litt.) the vernacular name 'Hog-nosed bat' for this species : it has also been described (J. T. Marshall, in litt.) as the 'Bumble-bee bat'.

\section{REVIEW OF DIAGNOSTIC FEATURES}

The current taxonomic arrangement of the Chiroptera derives largely from the work of Miller ( 1907 ) who based the higher categories largely on the structure of the shoulder girdle, the humerus, sternum, spine and pelvis, and of the skull and teeth, remarking (p. 45) that in a group of characteristically volant animals the chief taxonomic importance must be assigned to the development of the wings'. More recently, Walton \& Walton (I970) and Vaughan (I970a) have reviewed the structure of the skeleton among the families of bats and Slaughter (I970) has examined their dentition. Smith (I972) has reviewed a number of characters valuable in the classification of bats at the familial level and in examining the New World families relied greatly upon a more detailed examination of the humerus, the femur and tragus than did Miller, together with a lesser emphasis upon such features as acoustic emissions, hair structure, karyotypes, the histology of facial glands, ectoparasites, brain size and immunology, not always readily available to the systematist. The nature of the available material of Craseonycteris at present limits any study of the genus from the familial standpoint chiefly to the traditional characters employed by Miller, and to these have been added a number of features that seem relevant when considering the familial position of this unusual bat. A synopsis of the diagnostic features in the families of bats, with much other information, is given by Koopman \& Cockrum (1967).

\section{Muzzle}

The muzzle of Craseonycteris resembles that of the Rhinopomatidae (which includes but one genus, Rhinopoma) in several respects. As in that family the muzzle is laterally swollen and the nostrils open directly anteriorly in a thickened narial pad, which is surmounted by a low dermal ridge. The nostrils, however, differ sharply: in the Rhinopomatidae they are slit-like and valvular (usually closed in preserved specimens) and situated quite closely to the upper margin of the narial pad, inclined at about 30 degrees to the horizontal. In Craseonycteris the nostrils are wide, the 
inner margin straight, the outer margin sharply curved and they lie nearer to the upper lip, set more sharply to the horizontal at an angle of about 60 degrees. There is no definite internarial septum in the Rhinopomatidae, and the superior dermal ridge is basically an extension of the narial pad; in Craseonycteris the nostrils are separated by a clearly defined internarial septum which broadens in its upper part to form the base of a narrow superior dermal ridge extending over the central part of the narial pad, above the nostrils, and not completely across the pad as in the Rhinopomatidae. Among the Emballonuridae the nearest approach to Craseonycteris in the structure of the anterior muzzle is found in Balantiopteryx in which the nostrils are of similar shape and open anteriorly in the face of an anteriorly directed, nearly vertical pad and are separated by a wide septum, but there is no superior dermal ridge.

It may be conjectured that the low superior dermal ridge in Craseonycteris and perhaps in the Rhinopomatidae represents a rudimentary form of nose-leaf. A broadly similar but more developed structure occurs in the Vespertilionidae (in the subfamily Nyctophilinae), while in the Hipposideridae the broadened upper part of the internarial septum forms the base of the central part of a sometimes complex nasal foliation. Furthermore, among the Phyllostomatidae the spear-like nose-leaf is a direct extension of the anterior muzzle.

\section{Tragus}

The tragus of Craseonycteris is well developed as it is in the Rhinopomatidae, but tapered distally and not truncate as in that family. Among the Emballonuridae the tragus is spatulate or pyriform. In Craseonycteris the tragus is remarkable for the curious oblate swelling at the mid-point of its anterior part, common to both male and female specimens. A slight swelling of the anterior part of the tragus is sometimes to be found in the Rhinopomatidae.

\section{Wing structure}

This in Craseonycteris provides a number of interesting features deserving further comment. The propatagium is broad and unusually large, a feature associated by Vaughan (I970b : 2I0) with hovering flight, in allusion to the glossophagine bats. In this respect Craseonycteris differs sharply either from the Rhinopomatidae or from the Emballonuridae, in which the propatagium is narrow. The relation of the second and third metacarpals and their associated phalanges to the intervening wing membrane that they support follows a similar pattern in Craseonycteris and in the Rhinopomatidae, although the method of support differs. In Craseonycteris and in the Rhinopomatidae that part of the wing membrane lying between the second and third digits tapers from the end of the second digit to terminate distally about one quarter or a little more of the distance along the second phalange of the third digit from its junction with the first phalange. In the Rhinopomatidae this part of the membrane is supported anteriorly by a second digit with a metacarpal similar in length to the third metacarpal, together with two relatively long phalanges: the 
total length of the digit is equal almost to the combined lengths of the third metacarpal and its first phalange. A similar arrangement prevails in Craseonycteris although achieved in a different fashion: the second metacarpal is much longer than the third metacarpal, the very short phalange and its cartilaginous appendage contributing little to the total length of the second digit, which equals or slightly exceeds the combined lengths of the third metacarpal and its first phalange. In the Emballonuridae this part of the leading edge of the wing is relatively shorter, the membrane between the second and third digits terminating distally on the third digit at or about the junction of its first and second phalanges and supported solely by the second metacarpal which is shorter than the third metacarpal, although only slightly so.

The second digit in the Rhinopomatidae has two well-developed bony phalanges : this digit in the Emballonuridae, Nycteridae, Rhinolophidae, Hipposideridae, Natalidae, Furipteridae and Thyropteridae lacks phalanges while the Myzopodidae have a cartilaginous rod. The second digit in the remaining extant families of the Microchiroptera has one bony phalange but it is minute in the Mystacinidae and rudimentary in the Noctilionidae and Molossidae. In Craseonycteris the second digit has one very short, insignificant bony phalange, usually integrated with the metacarpal, tipped with a short cartilaginous appendage. As in Craseonycteris, there is no distinct third phalange on the third digit in the Rhinopomatidae, Emballonuridae, Nycteridae, Megadermatidae, Rhinolophidae, Hipposideridae and Noctilionidae. The third phalange is cartilaginous, but ossified at its extreme base, in the Natalidae, Furipteridae, Vespertilionidae and Molossidae: in the remaining extant Microchiropteran families the third digit has three bony phalanges.

In the graduation of the metacarpals, Craseonycteris differs quite markedly either from the Rhinopomatidae or from the Emballonuridae. In Craseonycteris the second metacarpal is the longest, the third the shortest, the fourth a little longer than the third and the fifth about as long as the fourth. In the Rhinopomatidae the second and third metacarpals are similar in length, the fourth considerably shorter, with the fifth longer and similar in length to the second and third. Among the Emballonuridae, the second is shorter than the third, the fourth yet shorter and the fifth the shortest : the tendency to shorten the fifth metacarpal in relation to the third and fourth is more pronounced among the larger genera. The relative wing proportions of many of the families of living Microchiroptera were studied by Revilliod (I9I6, tabs. I-5) who for numerous species expressed the lengths of the individual components of digits three to five as a percentage of the length of the forearm: the relative wing proportions for Craseonycteris are given in Table 3. The pattern of third metacarpal the shortest of metacarpals three to five, followed in length by the fourth metacarpal and with the fifth subequal to or longer than the fourth occurs most frequently in the Megadermatidae, the Rhinolophidae, infrequently in the Hipposideridae and in some Phyllostomatidae.

The length of the first phalange of the third digit in Craseonycteris is a little more than one quarter of the forearm length. In this respect Craseonycteris differs sharply from the Rhinopomatidae in which the length of the phalange is one sixth or less of the length of the forearm. The Furipteridae (not studied by Revilliod) 
also have a very short phalange, similar in relative length to that of the Rhinopomatidae. Among the Emballonuridae the length of the phalange varies from about one quarter to two fifths of the forearm length : in the Diclidurinae (not studied by Revilliod), however, the phalange is very short, like that of the Rhinopomatidae. In the Rhinolophidae, Hipposideridae, Noctilionidae, Mormoopidae, Desmodontidae and Mystacinidae the relative length of the phalange varies from a little less than one fifth to one third or slightly more of the length of the forearm : in the remaining Microchiropteran families the phalange is usually relatively rather longer although in some Phyllostomatidae its length may barely exceed one quarter of the forearm length. The second phalange of the third digit in Craseonycteris is exceptionally long, more than three quarters the length of the forearm and similar in length to the third metacarpal. In the length of this phalange Craseonycteris differs widely from the Rhinopomatidae, in which the phalange is about one third of the forearm length, or from the Emballonuridae, in which the phalange, although relatively longer in some species, only rarely equals one half of the forearm length. The relative length of the second phalange of the third digit in Craseonycteris is equalled only by the Noctilionidae, and, in the Vespertilionidae, by the Miniopterinae, although it is equalled or exceeded by the combined lengths of phalanges two and three in some Mormoopidae, by some species of Phyllostomatidae, notably in the Carolliinae and Stenoderminae, and by one of the genera of Desmodontidae. The Megadermatidae, some Kerivoulinae among the Vespertilionidae and some Molossidae approach Craseonycteris in the relative length of the second phalange of the third digit. Furthermore, in Craseonycteris this unusually long phalange is reflexed beneath the wing in specimens preserved in alcohol: reflexion of the proximal phalange of the third digit above the wing occurs in the Emballonuridae, Mystacinidae and Molossidae, and of the terminal phalange below the wing in the Noctilionidae and, among the Vespertilionidae, in the Miniopterinae.

The extreme shortness of the first phalange of the fourth digit in Craseonycteris, where it is about one sixth of the length of the forearm, is also an unusual feature. In the Rhinopomatidae the phalange is one fifth or more of the forearm length, and as a rule similarly so in the Emballonuridae, although exceptionally in this family the phalange may be a little less than one fifth of the length of the forearm. Among the remaining Microchiropteran families the Noctilionidae and rarely some Rhinolophidae resemble Craseonycteris in this respect. The first phalange of the fourth digit is relatively only a little longer in some others of the Rhinolophidae, in some species of the Mormoopidae and Desmodontidae, and in the Furipteridae. The second phalange of the fourth digit is shorter than the first phalange in the Rhinopomatidae, the Emballonuridae, Nycteridae, Thyropteridae (not studied by Revilliod) and Molossidae : in the Hipposideridae it is generally shorter than the first phalange, as it is with some exceptions, notably the Miniopterinae, in the Vespertilionidae. Otherwise, the second phalange of the fourth digit is longer than the first phalange : in Craseonycteris it is very long, its length exceeding two fifths of the length of the forearm and equalled in this respect only by the Noctilionidae and Miniopterinae. As in these, the terminal phalange is reflexed beneath the wing in specimens preserved in alcohol. 
The first phalange of the fifth digit in Craseonycteris is about one quarter the length of the forearm: in the Rhinopomatidae this phalange is very short, about one sixth of the forearm length and in the Emballonuridae rather longer, generally a little less than one quarter of the length of the forearm but on occasion as long as nearly one third of the forearm length. In the remaining extant Microchiropteran families the length of the phalange is generally between one fifth and one third or a little more of the length of the forearm but in certain of the Noctilionidae, some Mormoopidae and Desmodontidae and in some Vespertilionidae the relative length of the phalange is less than one fifth of the forearm length and the Mystacinidae in particular have a very short phalange, like the Rhinopomatidae. The second phalange of the fifth digit is longer than the first phalange, as in Craseonycteris, in the Megadermatidae, Rhinolophidae, some Hipposideridae, some Mormoopidae and Phyllostomatidae, the Desmodontidae, some Natalidae, the Mystacinidae and rarely in the Vespertilionidae. Otherwise it is equal to or shorter than the first phalange.

Revilliod (I9I6) summed the relative lengths of each digital component to provide a relative indication of the total length of each digit. This technique shows Craseonycteris (Table 3) to have a wing with broadly the same proportions as the wing of the Nycteridae. The Rhinopomatidae, Emballonuridae, Mormoopidae and Mystacinidae have digital proportions falling short of those for Craseonycteris : the proportions for digits three and four in Craseonycteris agree closely with the Noctilionidae but this family has a shorter fifth digit. The Rhinolophidae, Hipposideridae (except for digit five in Coelops) and Furipteridae also have relatively shorter digits. The digital proportions in the Megadermatidae, the Myzopodidae and the Thyropteridae approach those of Craseonycteris, as do some Phyllostomatidae and certain of the Desmodontidae and Natalidae: others of the same families exceed them. For the most part the proportions for digits three and four in Craseonycteris are exceeded by the Vespertilionidae but for digit five only by the Murininae and Kerivoulinae. Similarly, in the Molossidae the relative proportions for digits three and four exceed those of Craseonycteris, but digit five in the Molossidae is much shorter. In general terms, the wing of Craseonycteris is relatively wide and long, with a long tip.

In the same paper, Revilliod attempted to demonstrate the degree of adaptation to flight in the families that he examined by means of an index obtained by subtracting the length of digit five as a total percentage of the forearm length from the total percentage length of digit three. This technique emphasizes the position of species with long narrow wings in relation to those with short, broad wings: as might be expected, the Molossidae, some Vespertilionidae and some Phyllostomatidae occupy the highest positions with the greatest values of the index, but the results obtained display wide variation with some Vespertilionidae and some Phyllostomatidae in relatively low positions. This is perhaps inevitable when one aspect only of the chiropteran wing is examined. The figure obtained for Craseonycteris (Table 3 ) is low, its wing, although long, being comparatively wide, a combination obscured in the index employed by Revilliod.

More recently, the morphological properties of the chiropteran wing have been examined in some detail by Findley, Studier \& Wilson (1972). These authors have studied the relation between certain properties of the bat wing to the mode of flight. 
In particular, the aspect ratio (length from wrist to tip of third digit plus length of forearm, divided by width at fifth digit) and the tip index (length from wrist to tip of third digit, divided by the length of the forearm) seem especially relevant when considering Craseonycteris. In this genus (Table 3 ) the aspect ratio proves to be somewhat below the average demonstrated by Findley, Studier \& Wilson (I972 : 430, tab. I, 434, fig. I) for all bats. However, the tip index is very high, placing Craseonycteris among those bats (glossophagines, murinines, kerivoulines) which hover or are thought to do so, or are migrants or high speed foragers (miniopterines, lasiurines, molossids) (loc. cit. p. 430, tab. I, 436, fig. 2, 437). Furthermore, Findley, Studier \& Wilson suggest (p. 437) that the combination of a below average aspect ratio with a high tip index is especially suited for hovering flight, as might be the elongate wing tip. In the Rhinopomatidae there is a complete contrast : according to Findley, Studier \& Wilson (p. 430, tab. I, 434, fig. I) Rhinopoma has a below average aspect ratio, combined with the lowest tip index of any bat studied (p. 430, tab. I, 436, fig. 2) and, according to Harrison (Ig64:62) has an unusual, fluttering, undulating flight. Little is known of the mode of flight of the Emballonuridae, but in this family the aspect ratio was found by Findley, Studier \& Wilson (p. 430, tab. I, 434, fig. I) to be considerably above the average for all bats, and the tip index (p. 430, tab. I, 436, fig. 2) well below.

While variation in the proportions of the wing in the various Microchiropteran families is such that these features evidently cannot be used as a ready and reliable

\section{TABLE 3}

Wing proportions (forearm $=100$ ) and wing characteristics for Craseonycteris thonglongyai

\begin{tabular}{|c|c|c|c|c|c|c|c|}
\hline & & & के & & & 우우 & \\
\hline - & $\begin{array}{c}\text { Holotype } \\
\text { o TNRC } \\
54-387 \text { I }\end{array}$ & $\begin{array}{l}\text { No. of } \\
\text { speci- } \\
\text { mens }\end{array}$ & Range & Mean & $\begin{array}{l}\text { No. of } \\
\text { speci- } \\
\text { mens }\end{array}$ & Range & Mean \\
\hline $\mathrm{II}^{\mathrm{m}}$ & $102 \cdot 5$ & I 6 & $97 \cdot 2-102 \cdot 8$ & IOO·I & 9 & $100 \cdot 0-106 \cdot 2$ & $102 \cdot 5$ \\
\hline $\mathrm{III}^{\mathrm{m}}$ & $84 \cdot 4$ & I6 & $8 I \cdot 9-86 \cdot 7$ & $84 \cdot 3$ & 9 & $82 \cdot 5-87 \cdot 5$ & $84 \cdot 2$ \\
\hline III $^{1}$ & $28 \cdot 3$ & 16 & $26 \cdot I-28 \cdot 5$ & $27 \cdot 3$ & 9 & $26 \cdot I-29 \cdot 3$ & $27 \cdot 2$ \\
\hline III $^{2}$ & $82 \cdot 4$ & I 5 & $74 \cdot 5-88 \cdot 0$ & $82 \cdot 4$ & 9 & $76 \cdot 2-86 \cdot 7$ & $80 \cdot 7$ \\
\hline IIId total & $195 \cdot I$ & I4 & $183 \cdot 9-201 \cdot 4$ & 193.4 & 9 & I $85.8-203.5$ & $192 \cdot 6$ \\
\hline IV m & $93 \cdot 0$ & I6 & $88 \cdot 6-93 \cdot 2$ & $90 \cdot 8$ & 9 & $90 \cdot 3-96 \cdot 4$ & $92 \cdot 8$ \\
\hline$I^{1}$ & $16 \cdot 0$ & I6 & $14 \cdot 7-16 \cdot 9$ & I $5 \cdot 7$ & 9 & $14.5-16 \cdot 9$ & I 5.5 \\
\hline $\mathrm{IV}^{2}$ & $42 \cdot 2$ & I6 & $39^{\circ} 0-44^{\cdot} 2$ & $4^{I \cdot} \cdot 5$ & 9 & $39 \cdot 9-43 \cdot 4$ & $4 \mathrm{I} \cdot 4$ \\
\hline IVd total & $\mathrm{I}_{5} \mathrm{I} \cdot 2$ & $I_{5}$ & I $44^{\cdot} 5^{-I} 5^{2 \cdot 5}$ & $148 \cdot 4$ & 9 & I $45^{\cdot 8-I} 5^{6 \cdot 4}$ & $149 \cdot 7$ \\
\hline$V^{m}$ & $93^{\circ} 0$ & I6 & $88 \cdot 6-93 \cdot 0$ & $90 \cdot 9$ & 9 & $9 I \cdot 0-96 \cdot 9$ & $92 \cdot 9$ \\
\hline$V^{1}$ & 23.4 & I6 & $20 \cdot 8-23 \cdot 4$ & $22 \cdot 0$ & 9 & $20 \cdot 3-23 \cdot 2$ & $22 \cdot 4$ \\
\hline$V^{2}$ & $25 \cdot 0$ & I5 & $24 \cdot 5-28 \cdot 5$ & $25 \cdot 7$ & 9 & $23 \cdot 0-28 \cdot 0$ & $24^{\cdot 8}$ \\
\hline$V^{d}$ total & $I_{4} I_{4} \cdot 4$ & 14 & $I 36 \cdot I-I 43^{\circ} 0$ & $138 \cdot 6$ & 9 & $\mathrm{I} 37^{\cdot} \mathrm{I}-\mathrm{I} 4^{8} \cdot \mathrm{O}$ & $140 \cdot 0$ \\
\hline IIId total-Vd total & $53 \cdot 7$ & I 4 & $47 \cdot 2-6 \mathrm{I} \cdot 5$ & $54 \cdot 8$ & 9 & $4^{6 \cdot 5-5^{8} \cdot I}$ & $52 \cdot 6$ \\
\hline Aspect ratio & $2 \cdot 09$ & I4 & $2 \cdot 06-2 \cdot 17$ & $2 \cdot 11$ & 9 & $2 \cdot 05^{-2} \cdot 15$ & $2 \cdot 09$ \\
\hline Tip index & $I \cdot 95$ & I5 & $I \cdot 84-2 \cdot 0 I$ & I $\cdot 95$ & 9 & $I \cdot 85-2 \cdot 03$ & $\mathrm{I} \cdot 92$ \\
\hline
\end{tabular}

Aspect ratio $=I I I d$ from wrist to tip + forearm/width at $V^{d}$.

Tip index $=$ IIId from wrist to tip/forearm.

(IIId from wrist to tip $=I I I^{m}+I I I^{1}+I^{d} I^{2}$; width at $V^{d}=V^{m}+V^{1}+V^{2}$.) 
guide to classification at the familial level, it is clear that Craseonycteris cannot be allied closely either to the Rhinopomatidae or to the Emballonuridae from the structure of its wing, and that it is adapted for a quite different mode of flight from either of these. The relative proportions of digits three to five in Craseonycteris correspond reasonably closely to those of the Nycteridae (Revilliod, I9I6: I64, tab. I) or with certain of the Phyllostomatidae (loc. cit. p. I7o, tab. 3). The broad wing of Craseonycteris does not imply a bat adapted for fast or sustained flight, and, indeed, the structure of the wing suggests a hovering or at least a partially hovering species.

\section{Tail}

The tail is variable in the Microchiroptera. It may be present or absent (even within the family) ; its length may exceed the length of the uropatagium, or it may be subequal to this membrane in length or sometimes shorter, enclosed or partially enclosed within it, on occasion projecting from the posterior margin of the uropatagium or emerging through its upper surface. The Rhinopomatidae are unique among the living families in the presence of a long, slender, mouse-like tail, emerging from the edge of a reduced uropatagium. In the Emballonuridae the tail is shorter than the uropatagium and its free tip emerges through the upper surface about halfway or a little less along the length of the membrane. There is no external tail in Craseonycteris, but the uropatagium is moderate and rather full, an unusual feature in a tail-less species: Vaughan (197ob : $2 x_{4}$ ) remarked that a large uropatagium is found in some 'flycatcher' bats which forage near the ground or among vegetation, and which also have broad wings.

\section{Calcar}

As in the Rhinopomatidae, the uropatagium of Craseonycteris lacks calcarial support. Generally present in the Microchiroptera, the calcar is short or absent in some species of Phyllostomatidae, and rudimentary (on occasion not connected with the membrane) in the Desmodontidae, but in these the uropatagium is reduced: its absence in a species with a moderate membrane is unusual.

\section{Throat glands and pubic nipples}

Throat glands are found in the Emballonuridae, Phyllostomatidae, Vespertilionidae and the Molossidae, often associated with a pouch or sac (Quay, I970:23) : pubic nipples have been reported from the Rhinopomatidae, Megadermatidae, Nycteridae, Rhinolophidae, Hipposideridae, from the Nyctophilinae among the Vespertilionidae and possibly the Phyllostomatidae (loc. cit. p. 27).

\section{Lateral rostral swellings}

The rostrum is variously swollen or inflated in a number of Microchiroptera. Lateral rostral swellings, however, are noticeably characteristic of the Rhinopomatidae and Emballonuridae. In the Rhinopomatidae the swellings extend anteriorly 
beyond the narial aperture : those of Craseonycteris more nearly resemble the lateral swellings of the Emballonuridae.

\section{Premaxillae}

The structure of the premaxillae in Craseonycteris is unique, although it has clearly an overall resemblance to the arrangement found in the Rhinopomatidae and Emballonuridae. In neither of these, however, do the premaxillae fuse anteriorly, although as in Craseonycteris they are free from the adjacent parts of the skull, with the palatal branch short or absent, nor do their well-developed narial branches ever reach dorsally to the apex of the narial aperture and fuse together. In some Emballonuridae the premaxillae may lie partially on the surface of the maxillae, especially in Taphozous in which there is a very distinct approach towards the condition found in Craseonycteris. In Taphozous the ascending part of the narial branch is greatly developed and widened in its upper part, extending dorsad almost to enclose the narial aperture, the two premaxillaries separated at the apex of the aperture by a distance of about one third of the total width of the aperture. Posteriorly, the upper part of each narial branch is deflected into a narrow plate or lamina which lies on the surface of the maxilla. The inner edge of the narial branch is thrust forward anteriorly to form a sub-tubular flange at the side of the narial aperture, extending upwards to the outer upper part of the opening and terminating at the central division between the two branches. The premaxillae, therefore, form a structure similar in many ways to that prevailing in Craseonycteris, that is, a more or less tubular anterior projection partially surrounding the narial aperture, rising from a basal plate which rests on the maxillae and nasals, except that in Taphozous the surrounding ring and plate is incomplete, the narial branches failing to meet and fuse at the apex of the narial opening. The structure is rather less developed in Taphozous (Saccolaimus) than in T. (Taphozous) or T. (Liponycteris). In some other genera of Emballonuridae, for example in Coleura, Saccopteryx or Diclidurus, the narial branch of each premaxilla is widened to lie on the maxilla. A further stage from Taphozous is found in the Noctilionidae where the premaxillae are fused anteriorly and to the maxillae: the narial branches are unusually long and well developed, forming the sides of strongly tubular nares, separated above by the nasals. A similar arrangement prevails among the Mormoopidae. It is perhaps permissible to speculate that the sub-tubular structure in Craseonycteris supports the narial pad to which it is firmly attached by tough tissue. The free premaxillae in the Rhinopomatidae, the Emballonuridae and in Craseonycteris may serve to increase the mobility of the upper lip and the anterior part of the mouth when seizing food. They may also fulfil a similar function in the Nycteridae, Rhinolophidae and Hipposideridae but in these the premaxillae are represented only by their palatal branches and are cartilaginous in the two latter families.

\section{Dentition}

The dentition of Craseonycteris is very similar to that of Rhinopoma, with only a few relatively minor differences. The most obvious of these are the relatively larger 
upper incisors, the presence of a small antero-internal canine cusp, and the slightly further reduced condition of the third upper molar. Slaughter (I970:66) stated that in the Rhinopomatidae (mis-headed Rhinolophidae) the third upper molar lacks the pre-metacrista and that the hypocones of the upper molars are completely separate from the protoconal basins. However, in the majority of specimens the third upper molar has, as Miller (1907 : 82) pointed out, a metacone, mesostyle and three commissures : the mesostyle is invariably displaced and the third commissure or pre-metacrista is very short, terminating in an ill-defined metacone. Wear rapidly erodes the third ridge and metacone. The hypoconal basin of the first upper molar is broadly contiguous with the protoconal basin and separated only by a low commissure soon eroded by wear: in the second upper molar the basins are more definitely separated particularly in teeth with little wear.

\section{Humerus}

Apart from the early study by Miller (1907), the humerus of bats is discussed in considerable detail by Walton \& Walton (I970 : I05), Vaughan (I970a : Ir7 et seq.) and Smith (I972:I6). According to Vaughan (I970a: I30) modifications of the humerus for improved wing control are proximally the enlargement of the trochiter, the development of a supraglenoid fossa and of a large medial or deltoid ridge and, distally, the development of an epitrochlear or distal spinous process. These features are considered in greater detail, but for New World families only, by Smith (I972 : I6 et seq.).

\section{Proximal end of humerus}

Among the Microchiroptera the Rhinopomatidae, Emballonuridae, Nycteridae and Noctilionidae are sometimes considered primitive in that the trochiter is not greatly developed and proximally does not extend significantly beyond the head of the humerus, and a supraglenoid pit is lacking in the proximal face of the humerus at the anterior edge of the head. To these, Vaughan (r970a : I3I) adds that the medial ridge is weakly developed, but some of these have a prominent medial deltoid ridge. At the other extreme, the Vespertilionidae, Mystacinidae and Molossidae have a large trochiter which extends proximally well beyond the head, there is a deep supraglenoid fossa and the humerus has a substantial deltoid ridge. The remaining families form an intermediate group in which these characteristics are developed to varying degrees. The proximal extension of the trochiter apparently provides a locking mechanism which restricts the action of the humerus (Smith, I972: 28) rather than a 'secondary articulation' or 'double articulation' as Miller (r907) thought.

In Craseonycteris the trochiter is about as large as the trochin and extends proximally beyond the head of the humerus and a definite, deep supraglenoid fossa surrounded by the proximal part of a deltoid crest is lacking. Instead, the anterior part of the groove between the trochiter and the head of the humerus is deepened to provide a small fossa into which the supraglenoid tuberosity articulates. There is no deltoid ridge but the anterior face of the humerus is slightly elevated at the base of 
the trochiter, the elevation passing into a dorsal flange, and a similar ventral flange supports the trochin. The deltoid ridge is absent or very weak only in the Pteropodidae but in some Phyllostomatidae (Micronycteris, Glossophaga) and, among the Vespertilionidae in the Kerivoulinae, the deltoid crest is displaced dorsad, although only slightly so. The proximal end of the humerus in Craseonycteris thus differs sharply from those families considered primitive, and in the proximal extension of the trochiter approaches the Vespertilionidae. The lack of a definite deep supraglenoid fossa corresponds more closely to the allegedly primitive families, although the trochiter in Craseonycteris is separated from the head by a moderate groove with a shallow fossa, and the trochiter itself has small articular surfaces on its posterior face and on its ventral face opposite the humeral head. In Craseonycteris the head of the humerus is rounded, as in the Rhinopomatidae and in many of the other Microchiropteran families : it is elongate or oval in the Emballonuridae, Rhinolophidae, Hipposideridae and Noctilionidae, elliptical in the Megadermatidae and Mystacinidae and variable in the Phyllostomatidae.

\section{Distal end of humerus}

Certain features of the distal end of the humerus were employed by Miller (I907) in the familial classification of the Chiroptera. These included the size and position of the capitellum, the development of the lateral epicondyle or external condyle, of the trochlea or medial epicondyle and of the epitrochlea, sometimes called the internal condyle or medial process, and the presence or absence of an epitrochlear or distal spinous process. These structures are discussed in considerable detail by Smith (I972 : I6), in relation to the New World families, and by Felten, Helfricht \& Storch (I973) to European species.

\section{Capitellum, lateral epicondyle and trochlea}

These articular surfaces may vary in shape, size and proportion, and also in their degree of displacement dorsally from the axis of the shaft of the humerus. Variations in shape, size and proportion seem to offer little of familial significance. As a rule the central part of the capitellum is spherical or slightly oblong and forms the greater part of the articular surface: the lateral epicondyle is narrow and the trochlea similarly undeveloped, each separated from the principal surface by shallow grooves. The trochlea may become widened as in Diclidurus of the Emballonuridae to equal in width the central part of the capitellum, or the central part of the capitellum may be narrowed as in Mormoops of the Mormoopidae. In distal extension the trochlea may equal the lateral epicondyle, extend beyond it or beyond either the lateral epicondyle or the principal surface of the capitellum. This type of articulation, with some slight modification, is found in the majority of the families of Microchiroptera, but not in the Vespertilionidae or Molossidae. In these the principal part of the capitellum is angular or narrowed, and is tilted diagonally, a condition faintly foreshadowed in the Rhinolophidae and Hipposideridae, in which the otherwise spherical principal surface tends to be narrowed distally, or in the Nycteridae, where it is slightly oblique. The articular surfaces in Craseonycteris correspond 
closely to the first of these patterns and indeed closely resemble the pattern found in the Rhinopomatidae, most Emballonuridae and the Phyllostomatidae.

The displacement of the articular surfaces also varies between families. The capitellum in the Rhinopomatidae is slightly but distinctly displaced from the line of the shaft : it is similarly or more dorsally displaced in the majority of Microchiropteran families excepting the Emballonuridae, the Vespertilionidae and the Molossidae, although in some, such as the Noctilionidae and the Mormoopidae, as in the Rhinopomatidae, the degree of displacement is slight. In the Rhinolophidae and to a lesser extent the Hipposideridae the capitellum is widely displaced dorsally. In Craseonycteris the articular surfaces are slightly removed from the line of the shaft as they are in the Rhinopomatidae.

\section{Epitrochlea}

The epitrochlea or medial process may display varying degrees of development and ventral extension. In the Rhinopomatidae and for the most part the Emballonuridae, the epitrochlea is short and broad, the ventral portion sometimes curled: a similar process occurs in the Rhinolophidae and Hipposideridae. In the Nycteridae, Megadermatidae and Noctilionidae the epitrochlea is more massive and projects rather further ventrally : the Mormoopidae have a moderately developed epitrochlea, while among the Phyllostomatidae the epitrochlea varies from a relatively poorly developed condition to one displaying a moderate degree of development and ventral extension. The small families Natalidae, Furipteridae, Thyropteridae and Myzopodidae have a broad but rather short epitrochlea. The Vespertilionidae and Molossidae present a sharp contrast in a small, undeveloped epitrochlea which projects ventrally only slightly beyond the lateral line of the shaft. The epitrochlea in Craseonycteris is similar to that of the Rhinopomatidae, most Emballonuridae, or to those of the less developed processes found among the Phyllostomatidae.

\section{Epitrochlear process}

This is the spinous process of Miller (1907) or the distal spinous process of Smith (I972 : I7) which this author defined as the process extending distally from the tip of the epitrochlea or medial process. A second type of process is encountered in some families, arising not definitely from the tip of the epitrochlea, but from its distal margin. A similar, less developed structure is found among certain Phyllostomatidae, notably in Lonchorhina. Smith (I972 : 2I) advanced evidence to suggest that in this genus at least the structure is not homologous with the distal spinous process arising from the tip of the epitrochlea, but is a departure from the basically bilobed epitrochlea found in certain members of the family.

An epitrochlear process occurs in most of the Microchiropteran families, reaching an optimum in the Molossidae. It is absent from the Rhinopomatidae and absent or poorly developed in the majority of Emballonuridae although sometimes well developed as in Taphozous and Diclidurus. It occurs in the Rhinolophidae, Hipposideridae and Noctilionidae and is well developed in the Mormoopidae. The Phyllostomatidae have no epitrochlear process or at least only a weak development of it : 
a broad, low process is found in the Natalidae, Furipteridae, Thyropteridae and Myzopodidae. In the Natalidae, Furipteridae and Myzopodidae the dorsal base of the process is closely adpressed against the rim of the trochlea. The process is low but strong, virtually forming a part of the rim of the trochlea, in the majority of the Vespertilionidae, but is particularly well developed in the Miniopterinae, to equal the condition found in the Molossidae, in which the process is long, projecting well beyond the articular surfaces, and closely adpressed to the trochlear rim: the Mystacinidae also have a well-developed process. In the Nycteridae and the Megadermatidae the process is of the second type described above : in these Miller (I907 : I00) described it as 'styloid' rather than spinous : a similar process is found in some Rhinolophidae. It is of some interest to remark that the process is widely removed from the trochlear edge in the Emballonuridae, Rhinolophidae, Hipposideridae, Nycteridae, Megadermatidae, Noctilionidae and Phyllostomatidae. A variety of positions to one in which the process is almost in contact with the rim is found in the Mormoopidae (Smith, I972: I9, fig. 4). In Craseonycteris the process originates from the tip of the epitrochlea rather than from its distal edge, and is removed from the trochlear rim. It is similar to the process found in the Rhinolophidae or Hipposideridae, or to the less advanced of the Mormoopidae.

Vaughan (I970a : I30) remarked that the epitrochlear spine is not evident in the Rhinopomatidae, Emballonuridae, Noctilionidae and Nycteridae and is only fully developed in the Vespertilionidae, Mystacinidae and Molossidae, with the other families occupying an intermediate position. He concluded (p. I3I) that the primitive families lack the epitrochlear process while the advanced families possess it. However, the process is present in some of the allegedly primitive families, although in these it may take a rather different form from the process in those apparently more advanced. Vaughan (p. I32) further considered the development of the epitrochlear process a factor evolved in response to the need for lightening the distal parts of the wing so that the wings might be controlled more easily. A similar view is advanced by Smith (I972:23) who suggested that the process in the Mormoopidae and Molossidae forms part of an automatic flexing mechanism. It is perhaps not without significance that a well-developed process in one form or another occurs not infrequently in bats in which the third digit is elongated, even in families, for example, such as the Emballonuridae and Vespertilionidae in which the process either is not normally greatly developed or does not normally extend distally to any great extent.

\section{Scapula}

The modifications of the chiropteran scapula are briefly discussed by Walton \& Walton (I970:IO0) and by Vaughan (I970a:I28). The scapula in Craseonycteris has a number of relatively unmodified features: it is rather narrow, the supraspinous fossa is relatively large and lies in the same plane as the post-spinous part of the blade, the anterior flange is weak and the coracoid process is directed laterad. The infraspinous fossa, however, is quite strongly faceted, so that while in most respects the scapula resembles that of the majority of Microchiropteran families, in 
this feature it tends towards those in which the scapula is more specialized, such as the Molossidae, or Lasiurus or Miniopterus of the Vespertilionidae. This feature occurs also in Taphozous of the Emballonuridae, and, in this genus, in addition, the area of the supraspinous fossa is reduced, with a strong anterior flange. There is also in Craseonycteris a degree of articulation with the trochiter.

\section{Fusion of lumbar vertebrae}

In this respect, Craseonycteris resembles the Natalidae or the Furipteridae, also small, delicately formed bats. However, vertebral fusion occurs in some genera of the Hipposideridae and also in Kerivoula of the Vespertilionidae. As Miller (I907: I82) pointed out, the feature is of no value in determining familial position.

\section{Proximal end of femur}

The proximal end of the femur in Craseonycteris resembles the condition found in the Emballonuridae, with the lesser trochanter a little larger than the greater trochanter and extending a little further proximally. It differs from the Rhinopomatidae in which the lesser trochanter is similar in size to the greater trochanter but stands marginally a little lower. The head and neck of the shaft of the femur are not deflected from the line of the shaft as in the Rhinolophidae and Hipposideridae. There is considerable variability in the structure of the head of the femur among the Microchiropteran families (Smith, I972: 29, 30, fig. 8) but the femur has a more limited value in familial classification than has the humerus, although this author found the Mormoopidae to lack well-developed trochanters, in contrast to the other families that he had examined.

A summary of the more obvious characters discussed appears in Table 4.

\section{SYSTEMATIC POSITION OF THE CRASEONYCTERIDAE}

The new family Craseonycteridae resembles the Rhinopomatidae in some external features, some cranial characters and especially in the details of its dentition. In particular, the narial pad with rudimentary superior dermal ridge, the structure of the leading edge of the wing, the lack of calcarial support to the uropatagium, the swollen rostrum, the free premaxillae with prominent narial branch, the shape of the dental arcade and the architecture of the teeth themselves provide good characters in which it tends towards this monotypic family. At the same time, its unspecialized nostrils, large, independent ears, the tragus, the highly modified wing which contrasts sharply with the rather simple wing of the Rhinopomatidae, the lack of a tail and the features of the humerus, scapula and pelvis set it widely apart from the Rhinopomatidae. Although the new family has some features in common with the Emballonuridae, notably in the structure of the nostrils, the presence of rostral swellings and in the structure of the premaxillae which is clearly foreshadowed in some Emballonuridae, the Craseonycteridae differ widely from this family in many 
other features. Among these the tragus, the lack of a tail, the absence of postorbital processes and of basioccipital pits, the dentition and the organization of the shoulder joint seem particularly notable. Furthermore, the Craseonycteridae differ widely from the Emballonuridae in the overall structure and characteristics of the wing.

The Craseonycteridae differ so widely from the Nycteridae, Megadermatidae, Rhinolophidae and Hipposideridae that any close relation is most unlikely. There exist also wide differences from the Noctilionidae and Mormoopidae, especially in the form and structure of the rostrum, of the palate and teeth, and of the head of the humerus. As with all of these families, the premaxillae provide a major distinction between the Craseonycteridae and any of those remaining, although it also differs from these in numerous other features. However, in the structure of the humeral head the Craseonycteridae approach those families considered more advanced in this respect, beginning to some extent with the Phyllostomatidae and terminating with the Vespertilionidae, Mystacinidae and Molossidae, although the humerus in the Craseonycteridae is less modified in comparison with the last three of these. My conclusion is, therefore, that the Craseonycteridae must be classified with the Rhinopomatidae and Emballonuridae. The wing in the new family is clearly more modified than in either of these, perhaps for a mode of flight involving hovering, by the enormous extension of the third digit with the concomitant development of the humerus. For this reason the Craseonycteridae should follow the Rhinopomatidae and the Emballonuridae: few features of the new family suggest that it in any way intermediates between these two. It is more correct to say that it carries further features already apparent in one or other, or both, of these.

Current classification of the Chiroptera is usually based on Simpson (I945). This author assembled the families delineated by Miller (I907) into superfamilies. Smith (I972 : 39) remarked that these superfamilies were based on Winge's families as expressed in his work (I892) on the mammals of Lagoa Santa, Brasil, and that as a result the Noctilionidae were grouped with the Rhinopomatidae and Emballonuridae in the superfamily Emballonuroidea, while the mormoopids were carried as a subfamily of the Phyllostomatidae into the Phyllostomatoidea. However, Winge consistently (I892:24; I923:235; I942:27I) placed Noctilio with the mormoopid genera in the Phyllostomatidae, although Simpson (I945: I80) stated that his classification retains Miller's families but groups them into superfamilies which are those of Winge. Possibly in this instance in grouping the Noctilionidae with the Rhinopomatidae and Emballonuridae Simpson was influenced by the remarks of Miller (I907 : 97) where relationship between these families is suggested. The Craseonycteridae stand closer to the Rhinopomatidae and Emballonuridae than to either the Noctilionidae or Mormoopidae. For this reason the new family should be included with the rhinopomatids and emballonurids in any further grouping, preferably as a superfamily, the Emballonuroidea. Within this assemblage, the Craseonycteridae are the most advanced, especially in wing structure. Smith (I972:39 et seq.) advanced reasons for considering the Noctilionidae, Mormoopidae and Phyllostomatidae as three distinct families possibly forming another superfamily, the Phyllostomatoidea although he noted (p. 4I) that this grouping seemed premature. 
J. E. HILL

әер!ssojon । 1 1

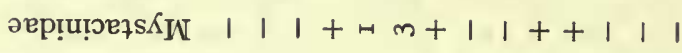

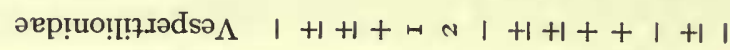
әер!podoz $K_{\mathrm{N}} \quad$ । 1 । + o 1 । $1+++1$ । әерцәәдолКч.I । 1 1 $0 m|1|+++1$ ।

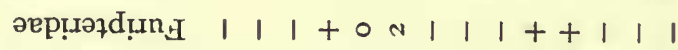

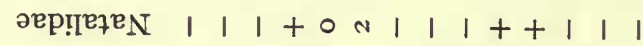




$$
\begin{aligned}
& +t+1+1+1 \quad 1++1+1+1+t++11+1 \\
& +++11+1++11++1++1111+1 \\
& ++1+1 \quad 1 \quad 1+t+11+1+t+1+11111 \\
& +t+11+1+t+11+t+1+1 \quad 1 \quad 1 \quad 1 \quad 1 \\
& +++11+1+t+11++1++1+111 \\
& ++1+11 \quad 1+++11++1+111+11 \\
& +++1+1+t+11++1++1+11 \\
& +++1+1+t+11++1+1111+1 \\
& +++11+1+t+11+t+1 \quad 1 \quad 1 \quad 1 \quad 1 \quad 1 \\
& +++11+1++1+1++11+111+111 \\
& ++1+1+1 \quad 111+1++1+111111 \\
& +111+11+t+1+1+t+1+t+111 \\
& +111+1 \quad 1++1+1+t+1+t+1111
\end{aligned}
$$

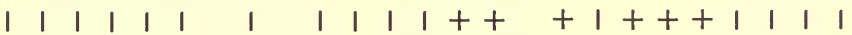

$$
\begin{aligned}
& +111+1 \quad 1 \quad 11+11++1+++111+ \\
& +11+1+t+t+111+1+111+11 \\
& +11+11 \quad 1 \quad 1 \quad 11+1+11+1111111 \\
& +11+11111+11++11111111
\end{aligned}
$$

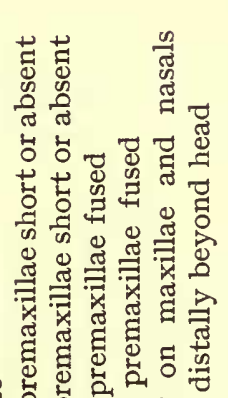

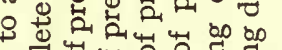

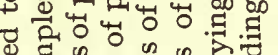

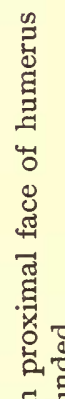

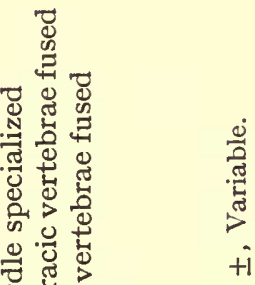


All are clearly distinct from the Rhinolophoidea, including the Nycteridae, Megadermatidae, Rhinolophidae and the Hipposideridae: the members of this superfamily have diverged considerably in different ways.

Smith $(1972: 40,4 \mathrm{I})$ reviewed the possible phylogeny and evolution of the New World families Noctilionidae, Mormoopidae and Phyllostomatidae, and concluded that for various reasons the commonly accepted view that the Microchiropteran bats evolved from an emballonuroid-like ancestor might be challenged. The further corollary to this hypothesis is that the New World noctilionids, mormoopids and phyllostomatids derive from an Old World emballonuroid migrant or migrants. Instead, Smith postulated a 'palaeochiropteran' ancestor in both the Old and New Worlds, thus providing a base for an autochthonous lineage for the New World bat families with which he was concerned. The family Craseonycteridae presents little that can be described as truly intermediate between the Rhinopomatidae and Emballonuridae on the one hand and on the other hand the Noctilionidae, Mormoopidae and Phyllostomatidae. However, some features might be considered in this way: the low dermal narial ridge, for example, might be construed as an incipient nose leaf, or the sub-tubular premaxillae, which are foreshadowed in the Emballonuridae and reach a further stage in the Noctilionidae and Mormoopidae, might be thought to display an intermediate condition.

Slaughter (1970:66) discussed the origins of the rhinopomatid dentition and pointed out that it could conceivably have taken origin from within the Emballonuridae. However, the structure of the hypo-protoconal basins in the Rhinopomatidae indicated to this author that this dentition could derive directly from a superfamily prototype, or from incipient emballonurid stock, the latter seeming to him more probable. The conclusion that the dentition of the Rhinopomatidae derives at least from an ancestral prototype rather than from within the Emballonuridae is reinforced by the Craseonycteridae in which the rhinopomatid dentition appears, little changed, in a bat otherwise widely removed either from the Rhinopomatidae or from the Emballonuridae, and, indeed, much more widely removed from the Noctilionidae or Mormoopidae. The new family emphasizes the difficulties and dangers of inferring phylogeny from a variety of modern forms each of which exhibits a varying combination of different specializations and modifications in different degrees. All that can be said is that the Rhinopomatidae, Emballonuridae and Craseonycteridae had most probably a common ancestry.

Miller (r907:8I) regarded the Rhinopomatidae as the most primitive of living microchiropteran families, largely on account of the presence of two phalanges in the second digit, the free premaxillae and the primitive shoulder joint. However, there is much to commend the views of Winge (I923:267; I94I : 3IO) who considered Rhinopoma, the sole representative of the family, to be rather isolated among living bats. In many respects, he averred, it is highly specialized, as in its dentition, the form of the nasal cavity and the upper arm, while other features, such as the premaxillae and the presence of two phalanges in the second digit, indicated a primitive origin. Winge noted that Miller had stated that in Rhinopoma there is no 'secondary articulation' between trochiter and scapula but that in fact a narrow articulation is present. Indeed, the trochiter may on occasion very slightly exceed the head of the 
humerus. As Winge pointed out, Miller placed much emphasis on the features that he regarded as primitive. It has long been customary to associate the Rhinopomatidae with the Emballonuridae (Dobson, I878 : 353 et seq. ; Winge, I892 : 33 ; I923 : 235; I94I : 27I ; or Simpson, I945:55) but there seems little in these features to suggest that the Rhinopomatidae are necessarily the more 'primitive'. The retention of two phalanges in the second digit of Rhinopoma may well be a corollary of the need to support a long leading edge of the wing, achieved in the Craseonycteridae by a relatively much longer metacarpal with insignificant phalangeal support: the simple shoulder joint with little modification of the proximal part of the humerus is perhaps a reflection of a correspondingly unspecialized wing. Furthermore, the valvular nostrils of Rhinopoma seem highly specialized : its long tail is an extreme of a variable chiropteran character and is possibly a 'primitive' feature although it may serve as a balancing organ in flight.

The Emballonuridae themselves are said by Miller (1907:84) to combine the greatest number of primitive characters with the least degree of specialization. Miller appears to have based this conclusion on the presence of postorbital processes, on the free premaxillae and the structure of the proximal part of the humerus. Yet the Emballonuridae display considerable modification of the premaxillae, varying from a comparatively simple condition in which the narial branches lie alongside the lateral margins of the narial aperture to the relatively advanced condition found in Taphozous in which a sub-tubular structure tending towards that found in the Craseonycteridae lies more or less on the surface of the maxillae. The deep basioccipital pits, sometimes divided by septa, seem also to be a specialized feature, and, as in the Rhinopomatidae, the number of teeth is reduced, although the process has not gone so far as in that family, only Taphozous among the Emballonuridae having lost one pair of lower incisors, while all emballonurids retain two upper premolars on each side. The wing in the Emballonuridae also presents some modification, with lengthening of the third digit in Taphozous and Diclidurus, and, throughout the family, with the flexing forward of its proximal phalange. The head of the humerus is slightly elongated and oblate in the Emballonuridae, rather than rounded, and slightly tilted, features possibly indicating a degree of specialization as Smith (I972: 29) suggested for the Mormoopidae.

The Rhinopomatidae, with but a single genus, mostly inhabit arid or semi-desert regions in southern Asia and Africa : by contrast, the Emballonuridae are widely distributed in the tropical and sub-tropical parts of the Old and New Worlds, with numerous genera and species. The Craseonycteridae have a wing and shoulder structure very different from either of these families, showing evidence of modification for specialized flight, most probably of a hovering nature. Nevertheless, the family retains the rhinopomatid organization of the anterior edge of the wing, to a considerable extent the architecture of the rhinopomatid skull, and especially the rhinopomatid dentition, with the premaxillae modified in such a way as to represent the epitome of a tendency foreshadowed in the Emballonuridae. Free premaxillae are common to all three families and are found (as the palatal rather than the narial branches) also in the Nycteridae, Rhinolophidae and Hipposideridae. They may well provide a flexibility contributing to a feeding mechanism that requires considerable 
mobility of the upper lip and anterior mouth and are possibly of value to bats that glean insects. The enlarged trochiter of the Craseonycteridae suggests conventionally a relatively advanced bat, yet in the absence of an evident deltoid ridge or a definite deep supraglenoid pit it differs from the other families so considered, although in some of these the ridge may be displaced dorsad, and in some the supraglenoid pit is not exceptionally developed and is displaced dorsad to lie between the base of the humeral head and the trochiter, as in the Craseonycteridae. The development of an epitrochlear process seems a corollary of a need to operate and control a long wing with a long tip. My view is, therefore, that this new and striking family of bats represents a further branch of the Emballonuroidea, modified for a sophisticated style of flight, and thus combining some external, cranial and dental features similar to those of the Rhinopomatidae and Emballonuridae with some of the wing and skeletal features of those families considered conventionally more advanced. Such a combination is perhaps inevitable when the familial classification of the Order is based to some extent on modifications which improve the flying mechanism or adapt it to particular kinds of flight, reflecting Miller's dictum quoted above that in a group of characteristically volant animals the greatest taxonomic importance must be placed on the development of the wings.

\section{ACKNOWLEDGEMENTS}

The late Kitti Thonglongya first involved me in the examination of this new bat and initiated the study of the specimens that he had obtained. The Board of the Applied Scientific Research Corporation of Thailand, through the Director of the Centre for Thai National Reference Collections, Dr Prasert Lohavanijaya, generously agreed that the work, begun as a joint enterprise, should be completed at the British Museum (Natural History) and made a series of specimens available to supplement the initial sample first brought to London by Mr Lim Boo Liat. My thanks are due to Dr H. Elliott McClure, of the United States Army Medical Component, South East Asia Treaty Organization, who helped in these arrangements after the death of Kitti Thonglongya, and to Dr R. Askins, then of the Association for the Conservation of Wildlife (ACW), Thailand, for his courtesy in informing me of that event. I am indebted to Dr J. T. Marshall, also of the United States Army Medical Component, who was instrumental in sending the major series of specimens to me in London, and for obtaining information and locational data necessary to the description of the new bat.

\section{SUMMARY}

A new family of bats, the Craseonycteridae, is proposed in the Microchiroptera for a new genus and species from Thailand, described as Craseonycteris thonglongyai. The new family is allied to the Rhinopomatidae and Emballonuridae and is placed in the Emballonuroidea. Its diagnostic features are reviewed in detail, with a discussion of its taxonomic position. 


\section{REFERENCES}

ANDERSEN, K. I905. On the bats of the Rhinolophus philippinensis group, with descriptions of five new species. Ann. Mag. nat. Hist. (7), $16: 243-256$, I fig., I tab.

Dobson, G. E. I878. Catalogue of the Chiroptera in the collection of the British Museum. London.

Felten, H., Helfricht, A. \& Storch, G. i973. Die Bestimmung der europäischen Fledermäuse nach der distalen Epiphyse des Humerus. Senckenberg. biol. 54 : 29I-297, I9 figs.

Findley, J. S., Studier, E. H. \& Wilson, D. E. I972. Morphologic properties of bat wings. J. Mammal. $53: 429-444,5$ figs., 4 tabs.

HARRISON, D. L. I964. The Mammals of Arabia. I. Insectivora, Chiroptera, Primates. London.

Hill, J. E. \& Thonglongya, K. I972. Bats from Thailand and Cambodia. Bull. Br. Mus. nat. Hist. (Zool.) 22 : I7I-I96, 4 figs., 2 tabs.

Koopman, K. F. \& Cockrum, E. L. I967. 6. Bats. In Andersen, S. \& Jones, J. Knox, Jr (Eds.), Recent Mammals of the World. A Synopsis of Families, pp. Io9-I50, II maps. New York.

Miller, G. S. I907. The families and genera of bats. Bull. U.S. natn. Mus. 57 : i-xvii, I-282, 49 figs., I4 pls.

QUAY, W. B. I970. I. Integument and derivatives. In Wimsat, W. A. (Ed.), Biology of Bats, II : I-56, I7 figs., I tab. New York \& London.

Revilliod, P. I9I6. A propos de l'adaptation au vol chez les Microchiroptères. Verh. naturf. Ges. Basel 27 : I56-1 83, 2 figs., 5 tabs.

Simpson, G. G. I945. The principles of classification and a classification of mammals. Bull. Am. Mus. nat. Hist. 85 : i-xvi, I-349.

Slaughter, B. H. I970. Evolutionary trends of Chiropteran dentitions. In Slaughter, B. H. \& Walton, D. W. (Eds.), About Bats. A Chiropteran Biology Symposium, 5I-83, 5 figs. Dallas.

Sмiтн, J. D. I972. Systematics of the Chiropteran family Mormoopidae. Misc. Publs Mus. nat. Univ. Kans. No. $56: \mathrm{I}-\mathrm{I} 32,40$ figs.

Thonglongya, K. I972. A new genus and species of fruit bat from South India (Chiroptera : Pteropodidae). J. Bombay nat. Hist. Soc. 69 : I5I-I 58, 2 tabs., 6 pls.

— I973. First record of Rhinolophus paradoxolophus (Bourret, I95I) from Thailand, with the description of a new species of the Rhinolophus philippinensis group (Chiroptera, Rhinolophidae). Mammalia $37: 587-597,2$ figs., 2 appendices.

— \& Hill, J. E. I974. A new species of Hipposideros (Chiroptera) from Thailand. Mammalia. $38: 285-294,2$ figs., 2 tabs.

Vaughan, T. A. I970a. 3. The skeletal system. In Wimsatt, W. A. (Ed.), Biology of Bats, I : 97-138, 23 figs. New York \& London.

- I970b. 5. Flight patterns and aerodynamics. In Wimsatt, W. A. (Ed.), Biology of Bats, I : I95-2I6, 4 figs., 3 tabs. New York \& London.

Walton, D. W. \& Walton, G. M. I970. Post-cranial osteology of bats. In Slaughter, B. H. \& Walton, D. W. (Eds.), About Bats. A Chiropteran Biology Symposium, 93-I26, 6 figs. Dallas.

Winge, H. I892. Jordfundne og nulevende Flagermus (Chiroptera) fra Lagoa Santa, Minas Geraes, Brasilien. Med Udsigt over Flagermusenes indbyrdes Slaegtskab. København. 
Winge, H. 1923. Pattedyr-Slaegter. I. Monotremata, Marsupialia, Insectivora, Chiroptera, Edentata. København.

- I94I. The Interrelationships of the Mammalian Genera (Ed. Jensen, A. S., SpÄRCK, R. \& Volsøe, H., translated Deichmann, E. \& Allen, G. M.). I. Monotremata, Marsupialia, Insectivora, Chiroptera, Edentata. København.

J. E. HILL

Department of Zoology

British Museum (Natural History)

Cromwell Road

LONDON SW7 7 BD 